B. J. QUALIHETM

DECTPIBER 1983

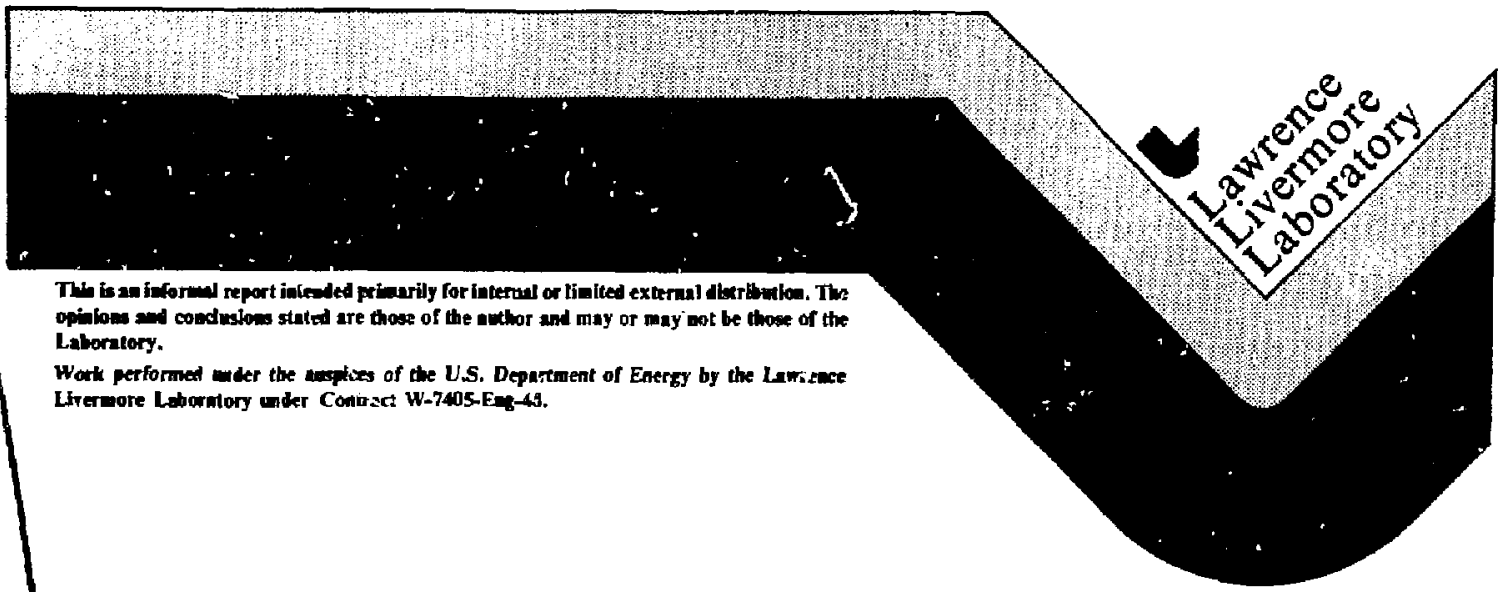




\title{
Mineralogic and Petrologic Investigation of Pre-Test Core Samples from the Spent Fuel Test-CJimax
}

by

\author{
F.J. Ryerson and E.J. Qualheim
}

\section{DISCLAIMER}

This report was prexared as an account of work sponsored by an agency of the United Staces Govetament. Neither the Uniled States Government nor any agsincy thereol, nor any of their employen, makes any warranty, expecss ot in-lied, or assumes any kfal lio'sility or responsibility for the accuracy, completenass, or usefuldess of any infomation, spairatus produch, of process disclosed, or represents that its use would not infringe privately owned rights. Reference herein to any specifie commercial praduct. process, of service by trade name, tredemark munufactuner, or otherwise does not necessarily canstitute or imply its endorsement, recomwendation, or favoring by the United States Government of any afency theteof. The views Lud opitions of authors expressed herein do nol necessarily state or reflect those of the United Statce Governmed or any akency thereof. 
ABSTRACT

Pre-test samples obtained from just inside the perimeter of the canister emplacement holes at the Spent Fuel Test-Climax have been characterized by petrographic and microanalytical techniques. The primary quartz monzonite has undergone various degrees of hydrothermal alteration as a result of natural processes. Alteration is most apparent on primasy plagioclase and biotite. The most comman secondary phases on plagioclase are muscovite and calcite, while the most comman secondary phases on biotite are epidote and chlorite. The major alteration zanes encountered are localized along filled fractures, i.e. veins. The thickness and mineralogy of the alteration zones can be correlated with the vein mineralogy, becaming wider and more complx mineralogically when the veins contain calcite.

\section{INTRODUCTION}

The Spent Fuel Test-Climax (SFT-C) is being ccnducted under the technical direcion of the Lawrence Livermore National Laboratory as part of the U.S. Department of Energy's Nevada Nuclear Waste Storage Investigations (NNWSI). The main objective of the SFT-C is to evaluate the technical feasibility of short-term emplacement and retrieval of spent reactor fuel asseriblies at plausible repository depth in granitic rocks (Ramspott et al., 1979). A secondary, though equally important, objective is the evaluation of a typical granitie rock's response to the thermal and radiation fields produced by the spent fuel assemblies. Simply, how are the physical, thermal and mineralogical properties of the country rock altered during the course of exposuse? These data are necessary if granitic rocks are to be qualified as possible long-term repositories for either spent fuel or reprocessed commercial and military reactor waste. 
In this report we present minerelogical and petrological data from the characterization of samples from the 17 canister core holes ( $\mathrm{CCH} 1-17$ ). These cores were obtained from just inside the perimeter of emplecement holes which were subsequently hammer drilled to $0.61 \mathrm{~m}$. diameter and loaded with either spent fuel assemblies $(1,3,5,7-12,14,16)$ or electrical simulators $(2,4,6,13,15,17)$ (Ramspott et al., 1981). The purpose of this investigation is to provide a data base of mineralogical compositions, assemblages ant modal proportions from pre-test samples to serve as a comparison to a similar data base that will be obtained from post-test samples. The post-test core samples will be obtained from just outside the perimeter of the canister emplacement holes directly adjacent (along a radius) to the pre-test core. This should allow us to determine whether or not any mineralogical changes have occurred ouring the course of the test. The close proximity of the pre- and post-test cores should also enable us to assess the possible migration of spent fuel, canister and/or alteration generated material along the various types of fractures in the quartz monzonite. The effects of spent fuel assemblies versus electrical simulators may also be investigated. In a more general application, detailed petrologic and mineralogic data is a necessity if the results of mechanical and thermal tests of these samples are to be fully understood.

In formulating an approach to this task it is worthwhile to consider the types of mineralogical phenomena that could occus during the time the fuel assemblies and electrical simulators are in place. Those that can alter mineralogic properties are:
1) hydration reactions
2) dehydration reactions
3) precipitation of new phases from solution
4) cation evchange

The first two processes can be evaluated, in large part, with strictly petrographic observations of mineral assemblages regaraing the presence of absence of key mineral phases. This is also true of the third process, although the possibility that a primary mineral may dissolve and then reprecipitate as a mineral of the same solid-solution series with a different camposition cannot be overlooked. 
The observation of the third process requires compositional data and, clearly, so do changes caused by the fourth process, cation exchange. As such, our approach is one of combined petrographic analysis and compositional analysis by electron microprobe techniques.

\section{GEOLOCIC SET TING}

The Climax stack, located an the U.S. Department fo Energy's Nevaca Test Site (NTS), is a composite granitic pluton composed of an equigranular biotite granodiorite and a porphyritic blotite quartz monzonite. The Cretaceous Age pluton is intruded into Paleozoic sarbonate rocks (Maldonado, 1977). The intrusion has caused recrystallization of the carbonates to form marbles, ano locally tungsten-bearing skarns are present. The SF T-C tunnel complex lies entirely within the quartz inonzonite.

\section{PREVIOUS INVESTIGATIONS}

Connolly (1981) has studiri the hydrothermal alteration of rocks from the SFT-C tunnel complex. This work pravides an excellent beckground for the present study as it is not restricted to wall-rock alteration in samples from only the CCH's, where the alteration is structurally controlled and afien poorly developed. His work concentrates upon alteration zones approximately $5 \mathrm{~m}^{3}$ in extent which display no epparent control by structural features. Th.a larger spatiol extent of the unlocalized elteration assemblages ailows more meaningful modal characterization of the alteration asseınblages (Table 1).

Including the pervasive deuteric alteration, five alteration types are observed: deuteric, propylitic, argillic, phyllic, ana potassic (Connolly, 1981). These alteration zones are often sharply defined and concentrically arranged progressing inward from deuteric to potassic. Tho average mades indicate that the presence or absence of certain key phases in the these alteration zones may be useful in classifying the structurally controlled localizeo wall-rock alteration : ones (Table 1). The potassic alteration is characterized by the high madil abuntance of K-feldspar ( $57 \mathrm{vol. \%}$ ) and low madal 
abundance of quartz $(5 \mathrm{vol} . \%)$. Phyllic alteration is charecterized by high madal abundances of muscovite $(30 \%)$ and calcite $(5$ vol. $\%$. The presence of kaolinite distinguishes ergillic alteretion; kaolinite has not been observed in any of the $\mathrm{CCH}$ samples characterized in this study. Deuteric and propylitic assemblages have quite similar modal abundances for almost all phases. Rutile, hematite and kaolinite are present in the propylitic assemblage, uui not in the deuteric; however, their abundances are insignificant. This modal similarity, coupled with the relatively poor development (i.e., limited spatial extent and overprinting) of the Jocalized alteration make it impossible to distinguish deuteric from propylitic alteration zones in localized alteration. Hence, both possibilities will be designated as deuteric alterstion.

The assemblages observed in the localized wall-rock alteration record either multiple alteration events or a single event with continuously variable temperature and fluid conditions. As such, the determination of physical conditions ouring alteration is equivocal. The better developed unlocalized wall-rock assemblages allow more reliable determination of these conditions. This data is important es it allows the possible range of physical conditions encountered subsequent to spent fuel and electricla simulator storage to be compered with the conditions encountered during hydrothermal alteration.

Connolly (1981) has estimated the external conditions for both deuteric and potassic alteration. In the deuteric zone, the thermodynamic expressions for the reactions

$$
\begin{aligned}
& \mathrm{An}+\mathrm{Or}+\mathrm{H}_{2} \mathrm{O}+\mathrm{CO}_{2}=\mathrm{Mu}+\mathrm{Cc}+2 \mathrm{Q} \\
& \text { 8nd } \\
& 4 \mathrm{An}+\mathrm{Or}+2 \mathrm{H}_{2} \mathrm{O}=\mathrm{Mu}+2 \mathrm{C}_{2} \mathrm{O}+2 \mathrm{Q}
\end{aligned}
$$

can be solved simultaneously ahong with the condition that the fluid is a binary $\mathrm{CO}_{2}-\mathrm{H}_{2} \mathrm{O}$ phase to yield a temperature of $370^{\circ} \mathrm{C}, \mathrm{X}\left(\mathrm{CD}_{2}\right)=0.018$. The ambient pressure determined by seconstruction of overturden is approximately I Kb (Ketner 1956, 1957; Barnes et al., 1963). 
The temperatures within the potassic zone are estimated from the two-feldspar geothermometer (Whitney and Stormer, 1977) and range between $335-430^{\circ} \mathrm{C}$. The maximum temperature experienced by the rock near the spent fuel canisters is $85^{\circ} \mathrm{C}$ (Patrick et al. 1981), hence, the conditions encountered during hydrothermal alteration were far in excess of those during the SFT-C.

\section{METHDDS OF STUDY}

\section{Sample Selection}

All samples described in this study were taken from cores obtained from inside the perimeter of the 17 canister emplacement holes. A reference line was drawn longitudinally along the recovered core. This reference line was then used to measure distances along the core and to determine the relative orientations of fractures for logging and sample selection.

The location and orientation of all fractures and alteration zanes in the 17 core samples was recorded at NTS. Using these core logs, 1- to 2-foot sections of core were selected using the following criteria:

1) top of core

2) bottom of core

3) sample representing (as closely as possible) "fresh" unaltered rock free of fractures, i.e., "bulk sample"

4) samples encompassing all the different types of alteration that could be described in hand specimen (it turns out that much of the sampling was redundent)

Criteria !-3 were fulfilled for each hole. Criterion 4 was only applied to holes of specific interest. The 1- to 2-foot core sections were sheri returned to LLNL for further selection.

After selecting the desired sample areas, a disk of the section cut perpendicular to the reference line was removed from the core. This disk was then cut in half (parallel to the reference line) and one piece retained at LLNL while the other was sent offsite for the preparation of polished thin sections. 
Petrography and Model Ar:alysis

All thin sections were observed in plane and cross-polerized transmitted light in order to determine mineral assemblages and textures (Appendix A). A number of samples were then point counted (2000 point modes) in transmitted light in order to determine modal abundançes. The samples selected for modal analyses are:
1) all samples from $\mathrm{CCH}-1$
2) the "bulk sample" from each hole

Samples from group (1) are used to demonstrate the variation in modal abundances in a specific hole. These variations are due to alteration and vein injection. The group (2) samples were chosen as "fresh" rock. Moual variations among these samples should, therefore, demanstrate the range of modal abundances in unaltered rock as a function of position along the conister drift.

Microprobe Analysis

Microprobe analyses were obtained in both automated and interactive modes employing a $2 \mu \mathrm{m} \times 2 \mathrm{\mu m}$ rastered beam at 15 na sample current (measured in a Faraday cup) with an accelerating voltage of $15 \mathrm{kV}$. The totally automated analyses were undertaken in order to abjectively deternine the frequency of $K$-feldsper and plagioclase compositions within selected samples. In this mode 300 analyses were obtained along a grid covering the sample surface. Approximately 600 12-element analyses we te obtained in a 24-hour period. The interactive analysis required operator selection of specific analysis points. This was done in order to determine the compositions of alteration phases which are normally low in the mads. 


\section{PETROGRAPHY}

\section{Unaltered Rock}

The quartz monzonite is a parphysitic rock composed of a groundmass which is predaminately equant, subhedral grains of plegicclase, K-feldoper, quartz, and biotite sanging in size from $0.5-2.0 \mathrm{~mm}$ in diameter. Igneous accessory phases \{titanite, altanite, xircon, and apatitel are below 3 volume $\%$ and show no effects of hydrothermal alteration (Conr.ally, 1981).

Plagioclase in the groundmess is tabular and elongate. Oscillatary zoning is a common feature, and polysynthetic twinning is ubiquitous. Plagiocjese commanly contains inclusions of clinozoisite, epiaote and calcite associated with hydrothermal alteration.

Quartz and K-feldspar ere present bath in the groundmass and as phenocrysts. In the groundmass both have anhedral to subhedral granular habits. The K-feldspars are untwinned, and the quartz commenly displays undulatory extinction. Phenocrysts of $K$-felospar ( $4-6 \mathrm{~mm}$ in length) are antedral and commonly perthic. Quartz phenocrysts $(3-15 \mathrm{~mm})$ are commonly composed of a number of smaller grains.

Biotite has a tabular habit and can the as lerge as $1 \mathrm{~mm}$. Biotite is commonly altereo to some subset of the minerals chlarite, muscovite, epidote, titenite, rutile, calcite, and pyrite.

Vein Mineralogy

Two distinctly different types of mineral essemblages are found in the veins within the canister orift region. The first vein, henceforth referred to as "barren," is composed of auartz with or without pyrite. Alteration zones adjacent to the barren veins are typically thin $(<5 \mathrm{~mm})$ and lack intense secondery mineralization. In particular, calcite is never found in these alteration zones. 
The second vein assemblage is composed of quartz, calcite, pyrite, and apatite. It may also contain grain of muscovite, K-feldspar and intensely altered plagioclase. The alteration zones adjacent to these "fertile" veins can be as large as $2 \mathrm{~cm}$ in diameter and often show intense alteration.

\section{Alteration of Plagioclase}

Plagioclase from the Climax stock is almost always altered to some combination of muscovite, epidote and calcite (Table 11). The alteration assemblages found here are similar to thase described by Ferry (1979) for mesozonal granitic plutons. The most common assemblages are (a) plagioclase and muscovite and (b) plegioclase, muscovite and calcite which are found in $43 \%$ and $35 \%$ of the sample areas studies, respectively (Appendix A). The alteration phases generally have irregular outlines, although muscovite is often present as fan-shaped aggregates. The percentage of plagioclase converted in a single grain can range from 0-75 volume $\%$, and the distribution of converted and unconverted is sporadic although greater conversion is noted near veins.

Photomicrographs of typical plagioclase alteration assemblages are presented in Figure 1 . It should also be noted that the plagioclase alteration assemblages can be correlated with the vein mineral assemblage about which they are localized. Assemblages $B$ and $D$ (from Table I1) are usually found adjacent to "barren" veins, while assemblages $C$ and $E$ art found adjacent to "fertile" veins.

In characterizing the plagioclase alteration assemblages, we have chosen not to distinguish clinozoisite from iran-bearing epidote. The complex zoning patterns make such a separation quite cumbersome for these samples. Figure 2 shows a backscattered electron image and corresponding $\mathrm{Fe}_{\mathrm{K}} \mathrm{X}$-ray image of an "epidote" grain included in altered plagioclase. The image illustrates discontinuous oscillatory zoning on a $10 \mathrm{um}$ scale in which the grain has compositions ranging from pure clinozoisite to Fe-rich epidote. 


\section{Alteration of Biotite}

The alteration of biotite in these samples is extremely complex and makes any classification scheme quite difficult. The secondery phases found on biotite include chlorite, muscovite, epidote, titanite, rutile, calcite, and pyrite (Appendix A). In any perticular sample, the number of phases found on biotite may vary. For instance, one biotite grain may include only chlorite while an adjacent grain contains chlorite and epidote. We have chosen to base our classification scheme on the maximum number of phases found on biotite rather than on the most frequent assemblage. The variability and, in some cases, large number of phases may be related to variability in the pore fluid composition during alteration and/or the variability in cation transport paths within the rocks.

A large variety of alteration assemblages are found on biotite (Table lli). The most common assemblages are (a) biotite and chlorite, and (b) biotite, chlorite and epidote and (c) chlorite, muscovite, epidote, and titanite which are found in $23 \%, 20 \%$ and $13 \%$, respectively, of the samples classified.

The alteration assemblages in Table III recoro a progressive loss of ison and magnesium from the biotite sites. This is first seen by the replacement of biotite by chlorite. Chlorite appears as symplectic intergrowths in biotite ( $F$ ig. 3a). A similar texture is observed in biotite-chlorite-epidote assemblages where biatite intergrowths are often crosscut by anhedral equent grains of epidote ( $F$ ig. $3 b$ and $c$ ). Further depletinn of iron and magnesium results in the complete disappearance of biatite. This often results in symplectic intergrowths of muscovite and chlorite which include scattered anhedral grains of epidote or titanite and/or rutile needles (Fig. 3d-f). Eventually, even chlorite may disappear leaving assemblages that are predominantly muscovite. An additional feature of the biatite-free somples is the presence of calcite after biotite. The calcite commonly appears along cleavage traces in chlorite or muscovite but may also be found as anhedral grains with these phases (Fig. jJ). 
Results of modal analyses for $\mathrm{CCH}-1$ samples and "bulk samples" from each of the $17 \mathrm{CCH}$ 's are presented in volume $\%$ and were obtained from 2000 point modes (Appendix B). Percentages of key phases have been plotted against sample position in Figures 4 ano 5 .

Modal analyses for the CCH-l were obtained from the entire thin section regardless of any sample heterogeneity. Material from veins, alteration zones and unaltered regions were all counted equally in order that sarople variability on this scale could be dacumented. Modal percentages for the primary phases, quert $z$, plagioclase, and $K$-feldspar, are fairly constant with average modal volumes of $17.3 \% \pm 2.1 \%, 32.8 \% \pm 5.6 \%$ and $31.2 \%+5.3 \%$, respectively. The 1 -sigma variation for plagioclase and $K$-feldspar are similar in spite of the much more pronounced alteration of plagioclase. Biotite is also a primary phase but displays a much larger percent variation than do the felsic phases. The average biatite volume is $4.9 \pm 2.7 \%$. The higher variability in biotite abundance is consistent with textural variability demonstrated earlier for biotite alteration.

Muscovite, chlorite, epidote, clinozoisite, titanite, and pyrite are present as secondary minerals. Their secondary origin is reflected in much larger variations in their madal abundance (Table IV, Fig. 4) and results from both variability in alteration down $\mathrm{CCH}-\mathrm{J}$ and to the presence or absence of veins which carried the hydrothermal solutions.

The modal abundances for the "bulk samples" have not been collected in inanner which includes the larger phenocrysts, and therefore, cannot be compared directly with the oata in Jable 1 in which only the groundmass phases were counted (the high modal abundance of K-feldspar phenocrysts may account for the generally lower abundance of quartz and higher modal abundance of K-feldspar in our data as compared to that of Connolly (1981)). Of the primary phases, only plagioclase appears to be significantly higher in the fresh "bulk samples" than in the variably altered samples from $\mathrm{CCH}-1$, $42.8 \%$ versus $32.8 \%$, respectively. This is consistent with the observation that plagioclase is the only felsic phase which undergoes significant alteration. 
The modal volumes of the secondery phases are as variable in the "bulk samples" as in those from $\mathrm{CCH}-1$ (Table V, Fig. 5). However, the average volumes of secondary phases in the bulk samples has decreased.

\section{MINERAL CHEMISTRY}

\section{Primary Phases}

The major primasy igneous rihases are quartz, plagioclase, $k$-feldspar, and biotite. Anslyses obteined in the interartive mode are presented in Appendix C. In addition to interactive analyses, feldspar analyses were also obtained by automated step-scan treyerses in order to objectively determint the extent of zoning and average feldsper compositions (Fig. 6).

Histagrams of feldspar analyses obtained from step-scan traverses indicate that the K-feldspar analyses vary between $\mathrm{Or}_{80}$ and $\mathrm{Or}_{98}$ with only occasional analyses falling at lower Or concentrations. The average analysis is $O r_{90}$, and shows very little variation from sample to sample. These values agree quite well with those obtained during the interactive analyses (Fig. 77. The K-feldspars shaw very little alteration, so that the variation must be due to a combination of primary igneous zoning coupled with subsolidus reequilibration.

The majority of the plagioclase composition fall between $A n_{20}-A n_{50}$ with the average at $\mathrm{An}_{33}$ (Fig. 6). Again, sample-to-sample variation in average analysis and frequency is small. In contrast to the K-feldspar analyses, comparison of the plagioclase analyses collected in outomated and interactive analyses show on important difference (Figs. 6 and 7). The interactive analyses facused upon plegioclese grairs which contained significant amaunts of secondary phases. This group of analyses contains significantly more analyses in the range $A n_{20}-A n_{0}$ than do those obtained in the automated step-scan traverses. This feature, which has also been abserved by Ferry (1979), is indicative of incongruent plagioclase alteretion. The albite endmember is conserved during hydrothermal alteration, while the anorthite component is preferentially dissolved and isansported from the plagioclase site. 
The biotite analyses can be represented by the formuls,

$$
K\left[\mathrm{Ti}_{0.2} 0.2^{(\mathrm{Fe}, \mathrm{Mg})_{2.4^{\mathrm{Al}}}}{ }_{0.2}\right]\left[\mathrm{Al}_{1.2} \mathrm{Si}_{2.8}\right]_{10} \mathrm{O}_{10}(\mathrm{OH})_{2}
$$

The $\mathrm{Mg} /(\mathrm{Mg}+\mathrm{Fe})$ ratio in these biotites lies between 0.50 and 0.68 (Fig. 8).

\section{Secondary Phases}

All data for secondary minerals was collected ir an interactive mode and is presented in Appendix C. The muscovite compositions fall in the range appraximated by the formula,

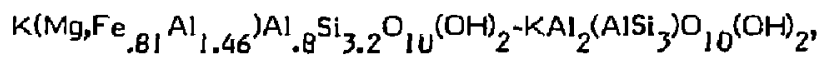

with a range in $\mathrm{Mg} /(\mathrm{Mg}+\mathrm{Fe}$ ) (atom) between $\mathrm{D}$ and $1 . \mathrm{D}$. When projected onto the plene $\left(\mathrm{Al}_{2} \mathrm{O}_{3}-\mathrm{K}_{2} \mathrm{O}\right)-\mathrm{MgO}-\mathrm{FeO}$ from quartz, $\mathrm{K}$-feldspar anu $\mathrm{H}_{2} \mathrm{O}$, it can be shown that the muscovites which are found to be pseudomorphing biotites are generally enriched in $\mathrm{MgO}$ and $\mathrm{FeO}$ relative to thase found on plagioclase ( $\mathrm{Fig} .9$ ). This is most likely indicative of increased activities of the components on the biotite sites and indicates that cation exchange equilibrium between plagioclase and biotite sites was not attained on even a thin section scale during hydrothermal alteration.

Chlorite is found exclusively an biotite sites, and its composition is given by the

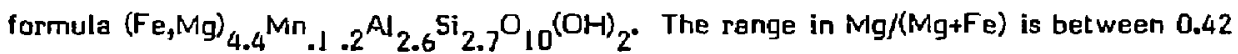
o.d 0.74 and is slightly larger than the range for the primary biotite (Fig. 8 ).

Mineral compositions and zoning patterns in the clinozoisite-epidote series are complex. The compositions are generally expressed by the formula $\mathrm{Ca}_{2}\left(\mathrm{Al}, \mathrm{Fe}^{3+}\right)_{3} \mathrm{Si}_{3} \mathrm{O}_{12}(\mathrm{OH})$. Given the complexity of the zonation, we have arbitrarily tabulated the analyses of this phase on plagioclase as "clinozoisite" and those on biotite as "epidote" (Afpendix C). Generally, the "epidates" found on biotite are more iron-rich than the "clinozoisites" found on plagiaclase. The $\mathrm{A}] /(\mathrm{Al}+\mathrm{Fe})$ in the epidotes ranges from 0.86-0.68 while that in the clinozoisites varies between 0.99 and 0.79 . A large variation in $\mathrm{Al} /(\mathrm{Al}+\mathrm{Fe})$ can occur in a single grain of clinozoisite. For instance, the enelyses of clinozoisites found on a single grain of "clinozoisite" in plagioclase (Fig. 2) cover a large portion of the field of clinozoisite-epidote analyses encountered in the entire study area (Fig. IC). 
For all practical purposes, the composition of pyrite can be assumed as $\mathrm{FeS}_{2}$ arid titanite as $\mathrm{CaTiSiO}_{5^{-}}$. The calcite compasition is given by the formula $\mathrm{Ca}_{.98} \mathrm{Mg}_{.01} \mathrm{Fe}_{.01} \mathrm{CO}_{3}$

\section{SUMMARY}

The data presented in this report document the chemical, petrographic and modal variations in core samples from the canister drift from the SFT-C. On a thin section scale $(3 \times 5 \mathrm{r}:$.$) ) significant variations in all of these properties are found. The variations$ result from both igneous processes and hydrothermal glteration localized along fractures.

Veriations due to primary inneous processes include zonation in plagioclase ano $K$-feldspar within a particular section. The renge end frequency of feldsper compositions has been documented through the une of an automated step-scenning procedure on an electron microprobe. Modal variations exist primarily due to the presence or absence of quartz and K-feldspar phenocrysts. It is worthwhile to note that chemical analyses of 500 $\mathrm{cm}^{3}$ samples displeyed relatively smaller sample-to-sample veriations then did modal analyses of thin sections $15 \mathrm{~cm}^{2}$ (Connolly, 1981). This is due to the relatively smaller contribution of phenocryst variations in the larger samples and should be considered in designing tests of physical properties for these rocks.

Features due to hydrothermal alteration are highly variable both within a particular section is well as between samples. Alteration zones (up to $2 \mathrm{~cm}$ wide) are localized along veins. The actual assemblages of secondary phases can be quite variable from sample to sample and from grain to grain of primery mineral phase. The compositions of some secondary phases (muscovite and epidote) can be shown to vary between different primary phase reaction sites, documenting gradients in chemical potentials of these components during hydrothermal alteration. The olteration assemileges also demonstrate that $\mathrm{CO}_{2}, 5$ and $\mathrm{H}_{2} \mathrm{O}$ were added to the rock during hydrothermal alteration. The source of this materiel is presumably the decarbunation of the carbonate country rack during the emplacement of the stock. 


\section{REFERENCES}

Connolly, J.A., "Hydrothermal alteration in the Climax grenite stock at the Neveda Test Site," Arizona State University, Tempe, AZ., unpublished M.S. Thesis. (1981)

Ferry, J.M., "Reaction mechanisms, physical conditions and mass transfer during hydrothermal alteration of mica and feldsper in granitic rocks from south-central Maine, U.S.A.," Contrib. Mineral. Petrol., 6B, 125139, (1979)

Maldonado, F., "Summary of geology and physical properties of the Climax Stock Nevada Test Site," Open File Report 77-356, U.5. Geological Survey, Washington, D.C. (1977)

Patrick, W.C., L.9. Ballou, T.R. Butkovitch, R.C. Carlson, W.B. Durham, G.L. Hage, E.L. Majer, D.N. Montan, R.A. Nyholm, N.L.Rector, D.C., Wilder and J.L. Yow, Jr., "Spent Fuel Test-Climax: Technical measurements, interim report, fiscal year 1981," Lawrence Livermore National Laboratory, UCRL53294, (1982).

Ramspott, L.D., L.B. Ballou, R.C. Carlson, J.E. Duncen, W.C. Patrick, D.G. Wilder, W.G. Brough and M.C. Mayr, "Technical concept for a test of geologic storage of spent reactor fuel in the climax granite, Nevada Tast Site," Lawrence Livermore National Laboratory, UCRL-52796 (1979).

Ramspott, L.D., L.B. Ballou and W.C. Patrick, "Stetus report on Spent Fuel Test-Climax: A test of geologic storage of High-Level waste in granite," Lawrence Livermore National Laboratory, UCRL-85516, (1981)

Whitney, J.A. and J.C. Stormer, "The distribution of $\mathrm{NaAlSi}_{3} \mathrm{O}_{8}$ between coexisting microcline and plagioclase and its effect on geothermometric calculations," Am. Min., 62, 687-691. 


\section{TABL.E I}

Average modes ${ }^{8}$, by volume percent, for minerais in altered quartz monzonite, exclusive of K-feldspar phenocrysts, corrected for porosity and statistically insignificant. variatione. Uncertainties ore at the $95 \%$ confidence interval. After Connolly (1981).

\begin{tabular}{|c|c|c|c|c|c|}
\hline \multirow[b]{2}{*}{ Mineral } & \multicolumn{4}{|c|}{ Alteration Type } & \multirow[b]{2}{*}{$\begin{array}{l}\text { Potassic } \\
\text { (14 } \\
\text { enalyses) }\end{array}$} \\
\hline & $\begin{array}{l}\text { Deuteric } \\
\text { (19 } \\
\text { anslyses) }\end{array}$ & $\begin{array}{l}\text { Propylitic } \\
\text { (12 } \\
\text { enalyses) }\end{array}$ & $\begin{array}{l}\text { Argillic } \\
\text { (13 } \\
\text { analyses) }\end{array}$ & $\begin{array}{l}\text { Phyllic } \\
\text { (5 } \\
\text { enalyses) }\end{array}$ & \\
\hline Plagioclase & $42.85 \pm 1.08$ & $39.16 \pm 2.38$ & $9.39 \pm 4.49$ & $20.45 \pm 8.83$ & $11.85 \pm 2.46$ \\
\hline K-feldspar & $17.97 \pm 0.82$ & $17.97 \pm 0.82$ & $17.97 \pm 0.82$ & $17.97 \pm 0.82$ & $56.88 \pm 3.89$ \\
\hline Quartz & $27.17 \pm 1.23$ & $27.17 \pm 1.23$ & $27.17 \pm 1.23$ & $27.17+1.23$ & $4.83 \pm 2.57$ \\
\hline Biotite & $5.38 \pm 0.53$ & $4.44 \pm 0.80$ & $3.26 \pm 0.97$ & - & -- \\
\hline Muscovite ${ }^{\mathrm{c}}$ & $1.48 \pm 0.28$ & $3.27 \pm 0.74$ & $6.27 \pm 3.29$ & $24.59 \pm 6.73$ & $12+89 \pm 2.55$ \\
\hline Chlorite & $0.99 \pm 0.18$ & $1.2 B \pm 0.34$ & $0.02 \pm 0.04$ & -- & $0.04 \pm 0.08$ \\
\hline Calcite & $0.30 \pm 0.08$ & $1.34 \pm 0.35$ & $8.13 \pm 1.94$ & $4.83 \pm 1.69$ & $5.20 \pm 0.93$ \\
\hline Clinozoisite & $0.55 \pm 0.05$ & $0.55 \pm 0.05$ & - & -- & -- \\
\hline Epidote & $0.18 \pm 0.02$ & $0.18 \pm 0.02$ & - & - & -- \\
\hline Kaolinite & -- & $0.57 \pm 0.85$ & $22.64 \pm 5.42$ & $0.52 \pm 0.97$ & - \\
\hline Smectite & $0.07 \pm 0.05$ & $0.46 \pm 0.37$ & $0.50 \pm 0.39$ & $0.22 \pm 0.45$ & -- \\
\hline Titanite & $0.44 \pm 0.10$ & L. $.27 \pm 0.10$ & - & $0.05 \pm 0.13$ & -- \\
\hline Rutile & -- & $0.17 \pm 0.12$ & $0.74 \pm 0.16$ & $0.54 \pm 0.65$ & $0.53+0.16$ \\
\hline Magnetite & $0.78 \pm 0.17$ & $0.31 \pm 0.12$ & - & $\cdots$ & -- \\
\hline Hematite & -- & $0.13 \pm 0.05$ & $0.43 \pm 0.17$ & -- & -- \\
\hline Pyrite & $0.03 \pm 0.03$ & $0.16 \pm 0.06$ & $0.15 \pm 0.13$ & $1.33 \pm 1.04$ & $0.46 \pm 0.20$ \\
\hline
\end{tabular}

a Accessories apatite, allanite, hornblende, and zircon do not vary significantly in eny of the altered rocks and have average modes of $0.26,0.04,0.02$, and 0.01 percent, respectively.

b Includes deuteric K-feldspar that has a mode of 0.10 percent.

c On the average, $95 \%$ of muscovite grains ere on plagioclese; the remainder occur on biotite. 
TABLE II

MINERAL ASSEMBLAGES FORMED DURING THE ALTERATION OF PLAGIOCLASE
A. Pc
(10)
B. Pc, Mu
C. Pc, Mu. Cc
D. Pc, Mu, Ep
E. Pc, Mu, Ep, Cc

Number in parentheses indicates the number of regions found with $\mathrm{a}$ particuiar assemblage. 


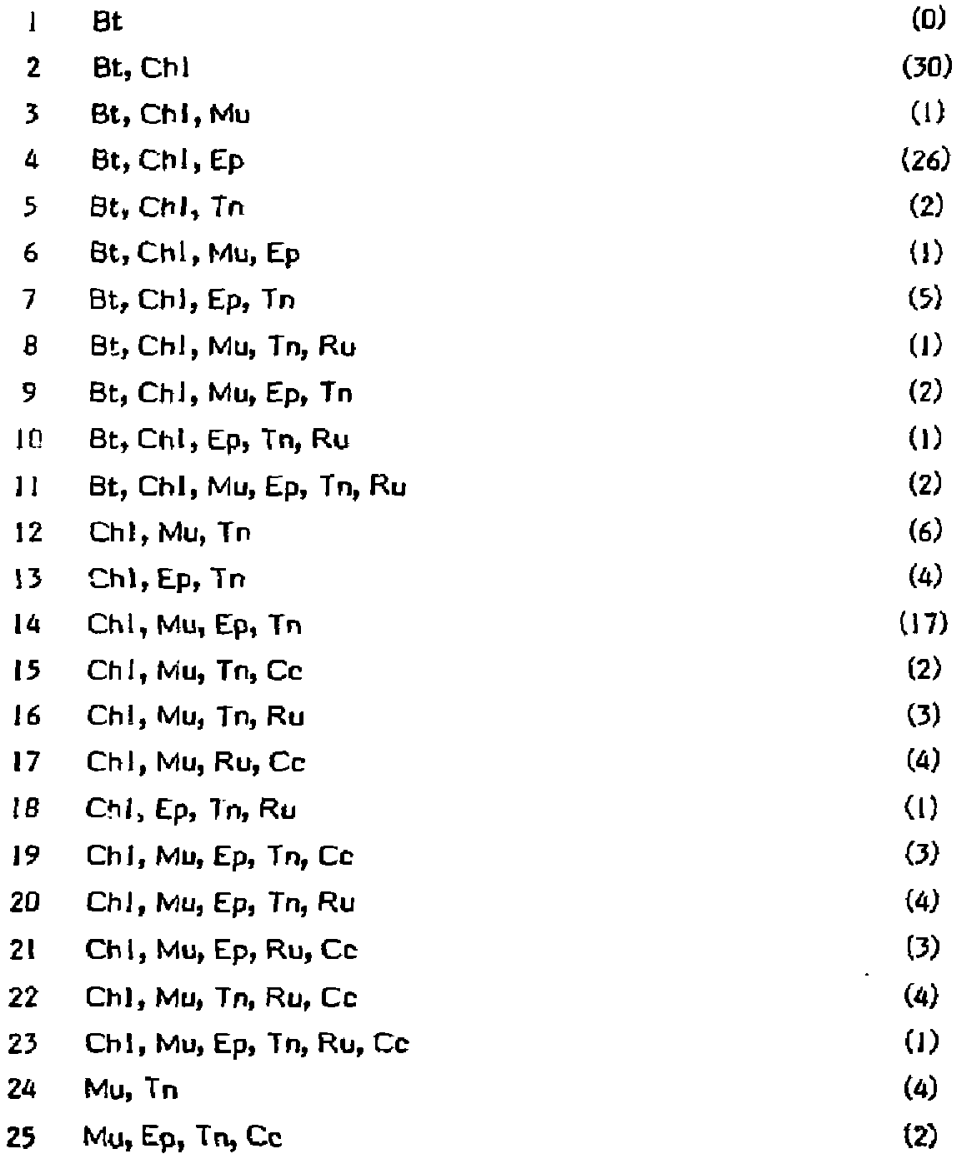

Number in perentheses indicates the number of regions found with a particular assemblage. 
TABLE IV

OBSERVED COMBINATIONS OF BIOTITE AND PLAGIOCLASE

ALTERATION ASSEMBLAGES

\begin{tabular}{|c|c|c|c|c|c|c|c|c|}
\hline A2 & (5) & $\mathrm{B2}$ & (21) & $\mathrm{C}_{4}$ & (1) & $\mathrm{D} 2$ & (3) & E2 \\
\hline \multirow{17}{*}{\multicolumn{2}{|c|}{ A4 }} & 83 & (19) & $\mathrm{C}_{6}$ & (1) & D4 & (1) & El2 \\
\hline & & 84 & (1) & $\mathrm{C7}$ & (2) & D7 & (1) & EI4 \\
\hline & & B5 & (2) & $\mathrm{CB}$ & (i) & D9 & (1) & E18 \\
\hline & & $B 7$ & (2) & $\mathrm{CII}$ & (1) & D) 4 & (2) & E24 \\
\hline & & $B 9$ & (2) & $\mathrm{Cl} 2$ & (4) & & & \\
\hline & & BII & (I) & $\mathrm{Cl3}$ & (3) & & & \\
\hline & & $\mathrm{B} 12$ & (1) & $\mathrm{Cl} 14$ & (6) & & & \\
\hline & & $B 13$ & (1) & CI5 & (1) & & & \\
\hline & & Bl4 & (2) & $\mathrm{C} 16$ & (3) & & & \\
\hline & & $B 15$ & (1) & $\mathrm{Cl}$ & (4) & & & \\
\hline & & $\mathrm{B} 20$ & (1) & C19 & (3) & & & 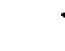 \\
\hline & & 822 & (1) & $\mathrm{C} 20$ & (3) & & & \\
\hline & & & & $\mathrm{C}_{21}$ & (3) & & & \\
\hline & & & & $\mathrm{C} 22$ & (3) & & & \\
\hline & & & & $\mathrm{C} 23$ & (1) & & & \\
\hline & & & & $\mathrm{C} 24$ & (3) & & & \\
\hline & & & & $\mathrm{C} 25$ & (3) & & & \\
\hline
\end{tabular}

Number in parentheses indicates the number of regions found with a particular assemblage. 

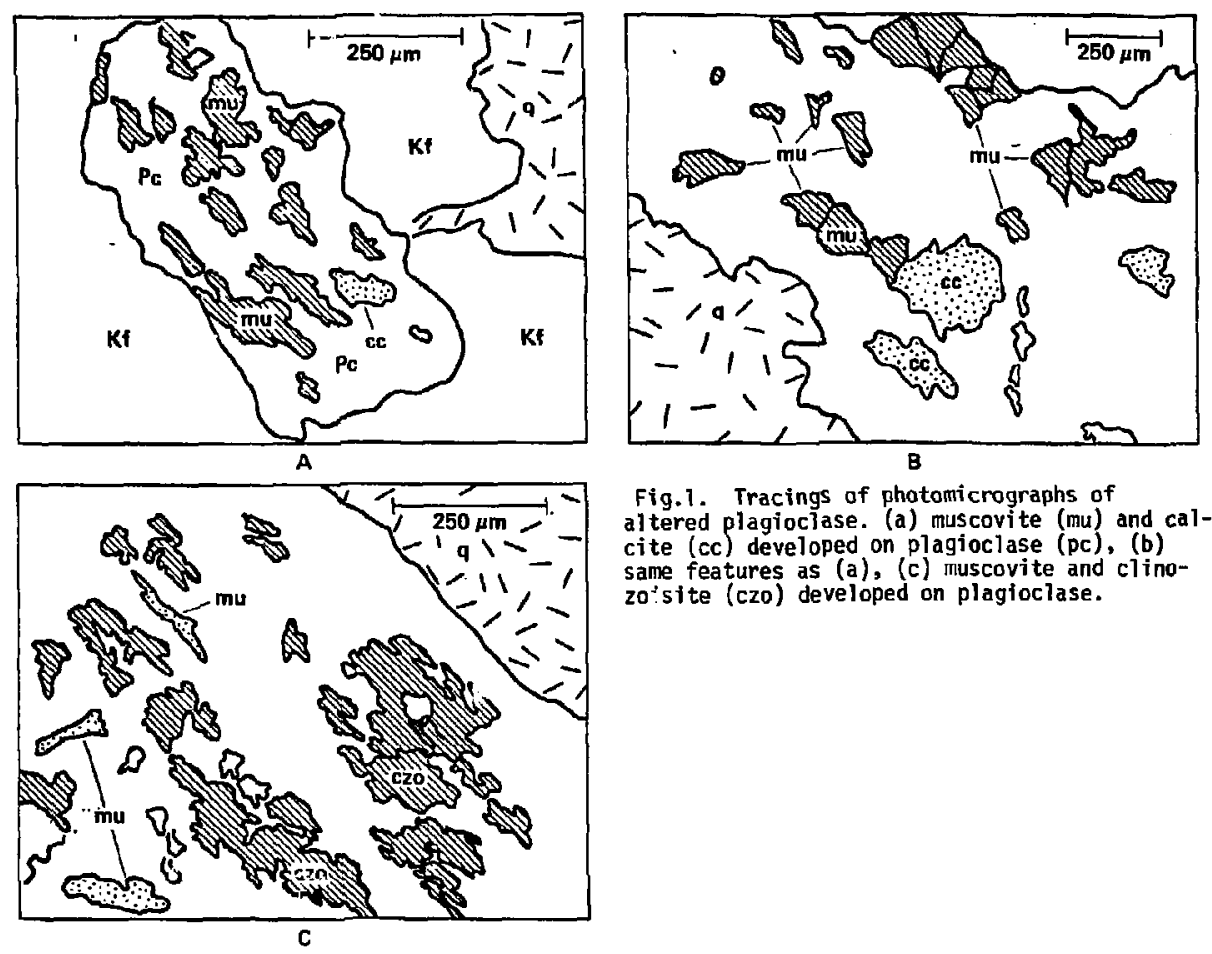

Fig. 1. Tracings of photomicrographs of a) tered plagiociase. (a) muscovite (mu) and calcite (cc) developed on plagioclase (pc), (b) same features as (a), (c) muscovite and clinozo:site (czo) developed on plagioclase. 

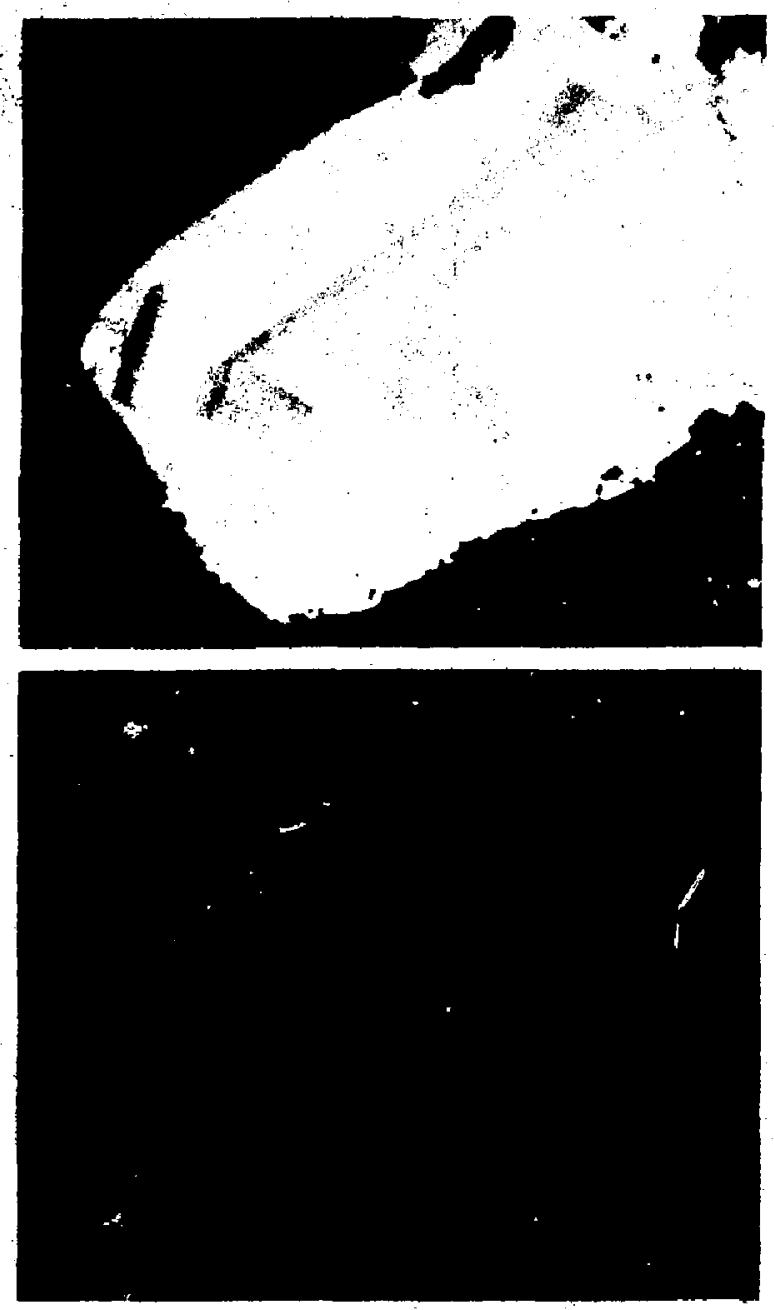

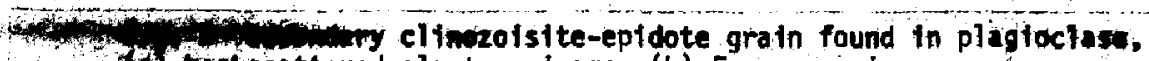
11 ragtectered electron image, (b) $\mathrm{Fe}_{K} \times$-ray image. 


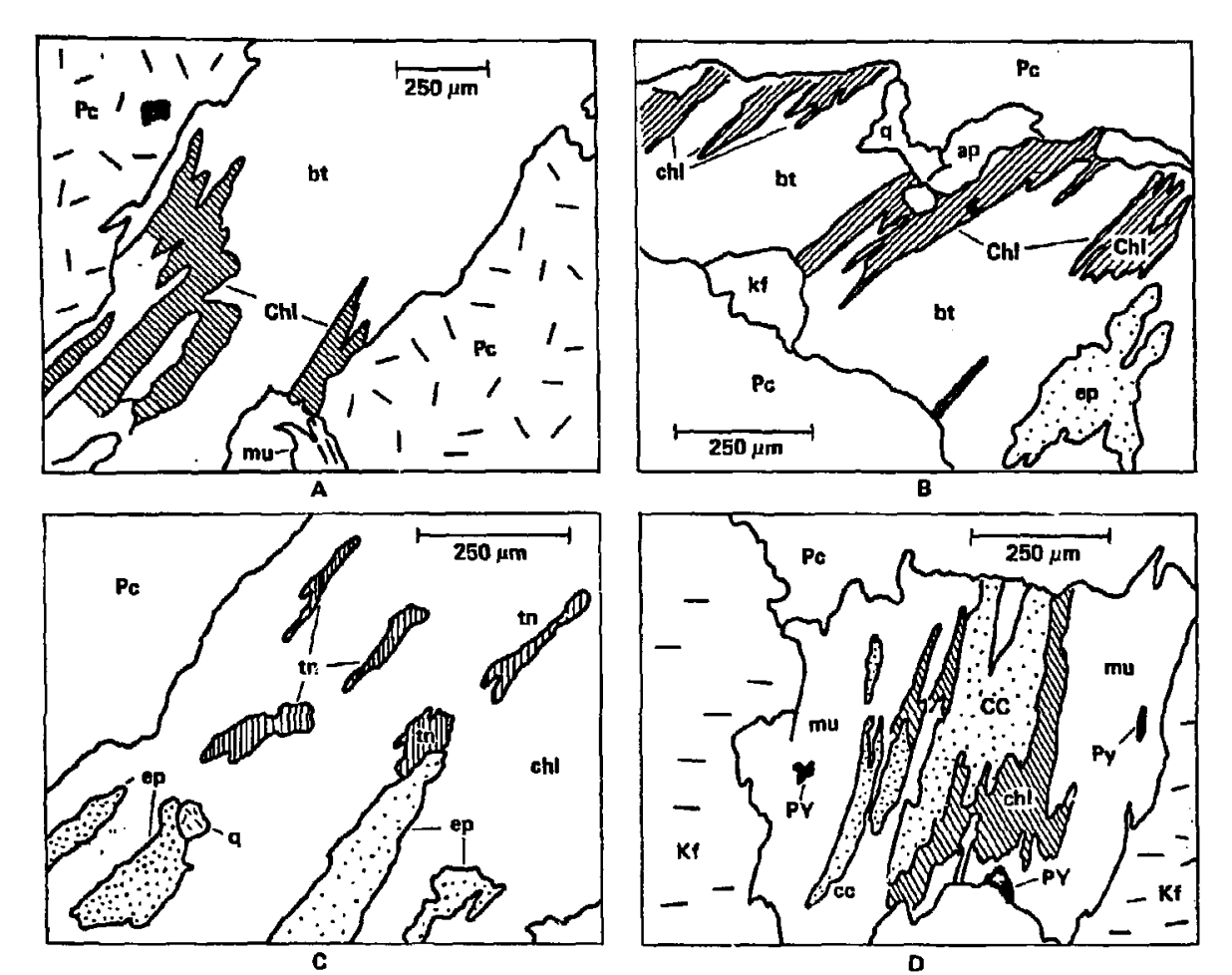



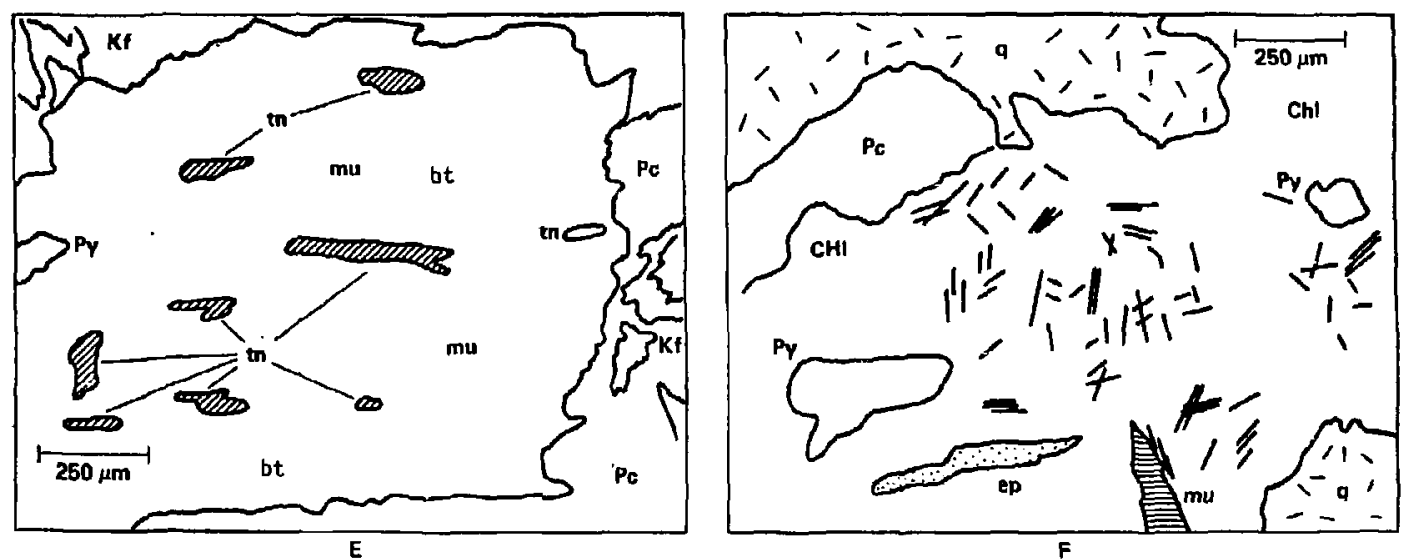

Fig. 3. Tracings of photomicrographs of biotite alteration. (a) Chlorite developed on biotite, (b) chlorite and epidote developed on blatite, (c) eptdote, titanite, chlorite and quartz after biotite, (d) chlorite, calcite, muscovite and pyrite after biotite, (e) muscovite, titanite and pyrite after biotite, (f) chlorite, epidote, muscovite, pyrite and rutile (needies) after biotite. Symbols, bt=biotite, chl=chlorite, ep=epidote, tn=ti tanite, $p y=p y r i t e, p c=p l a g l o c l a s e, c c=c a l c i$ te, mu=muscovite, $q=q u a r t z, k f=k-f e l d s p a r$. 


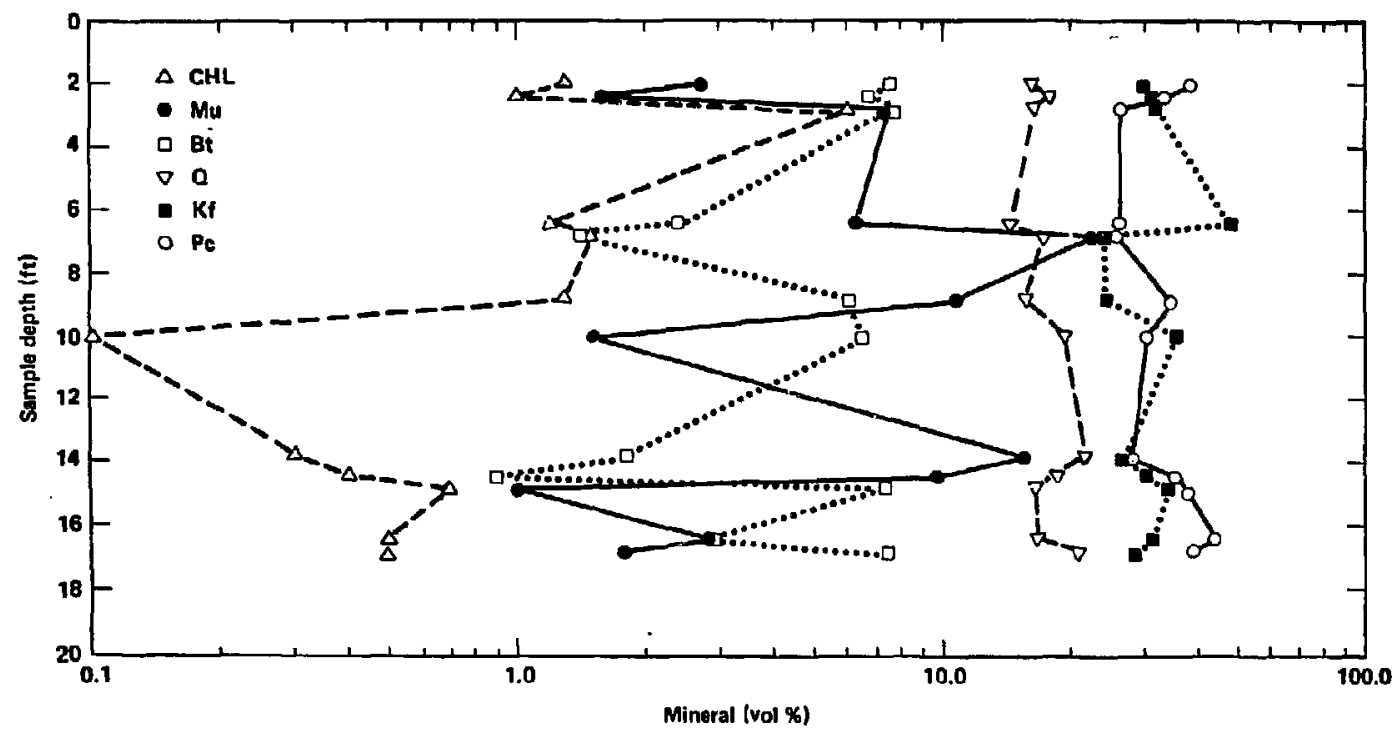

Fig. 4. Modal proportions of major phases in CCH-l samples plotted versus sample depth. 


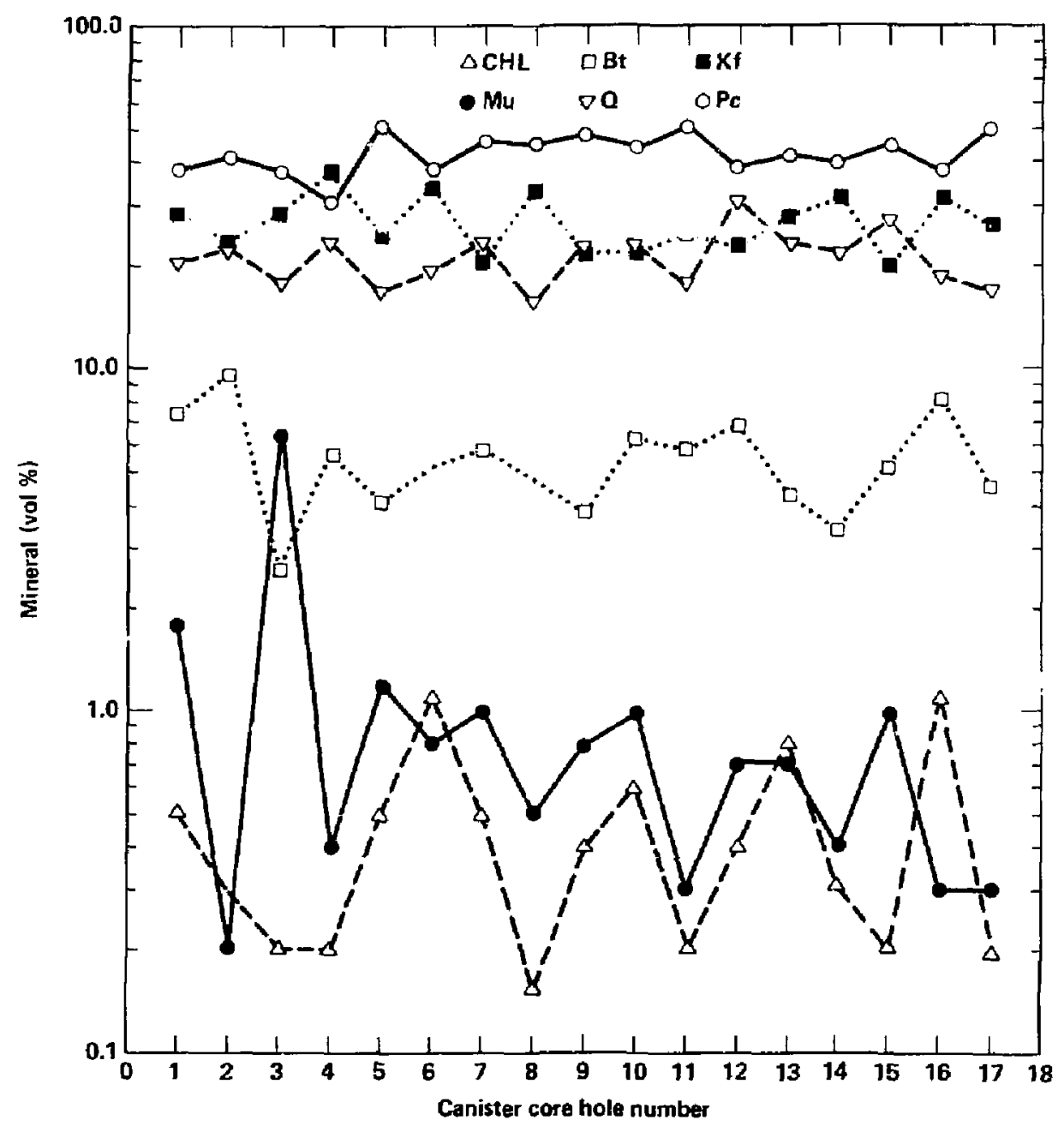

Fig. 5. Modal proportions of major mineral phases from "bulk" samples plotted iersus canister core hole position. 

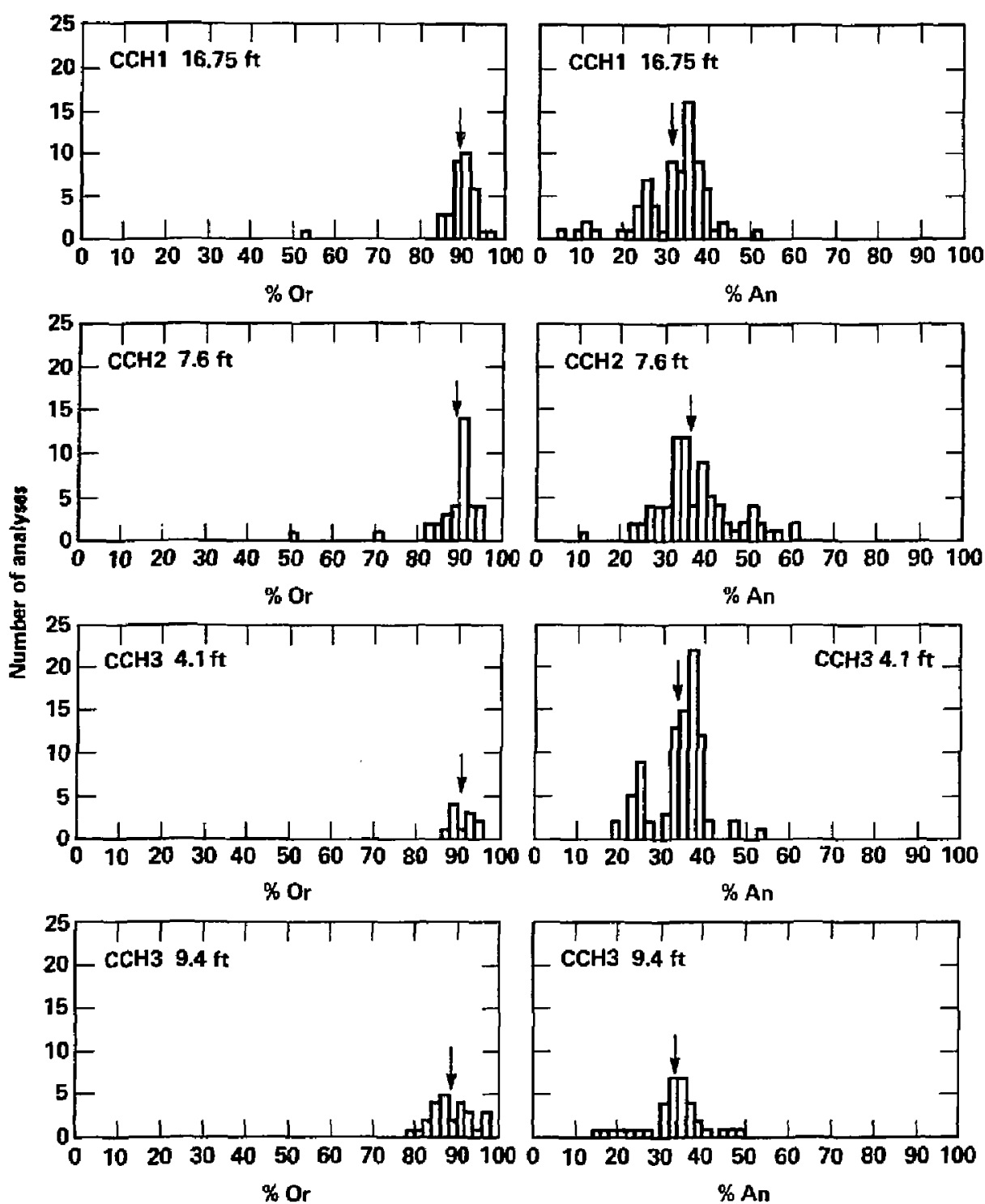

$\%$ An

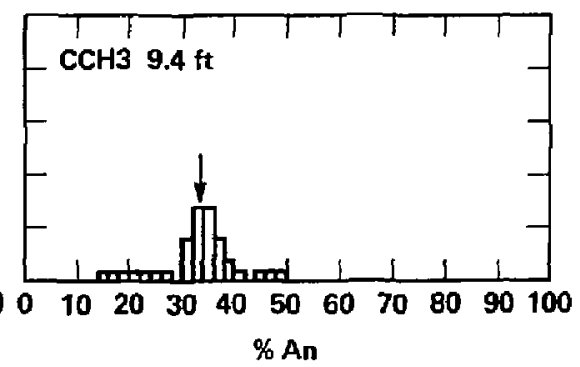

Fig. 6a. Histograms of feldspar analyses, arrows indicate average analysis, depth given in feet. 

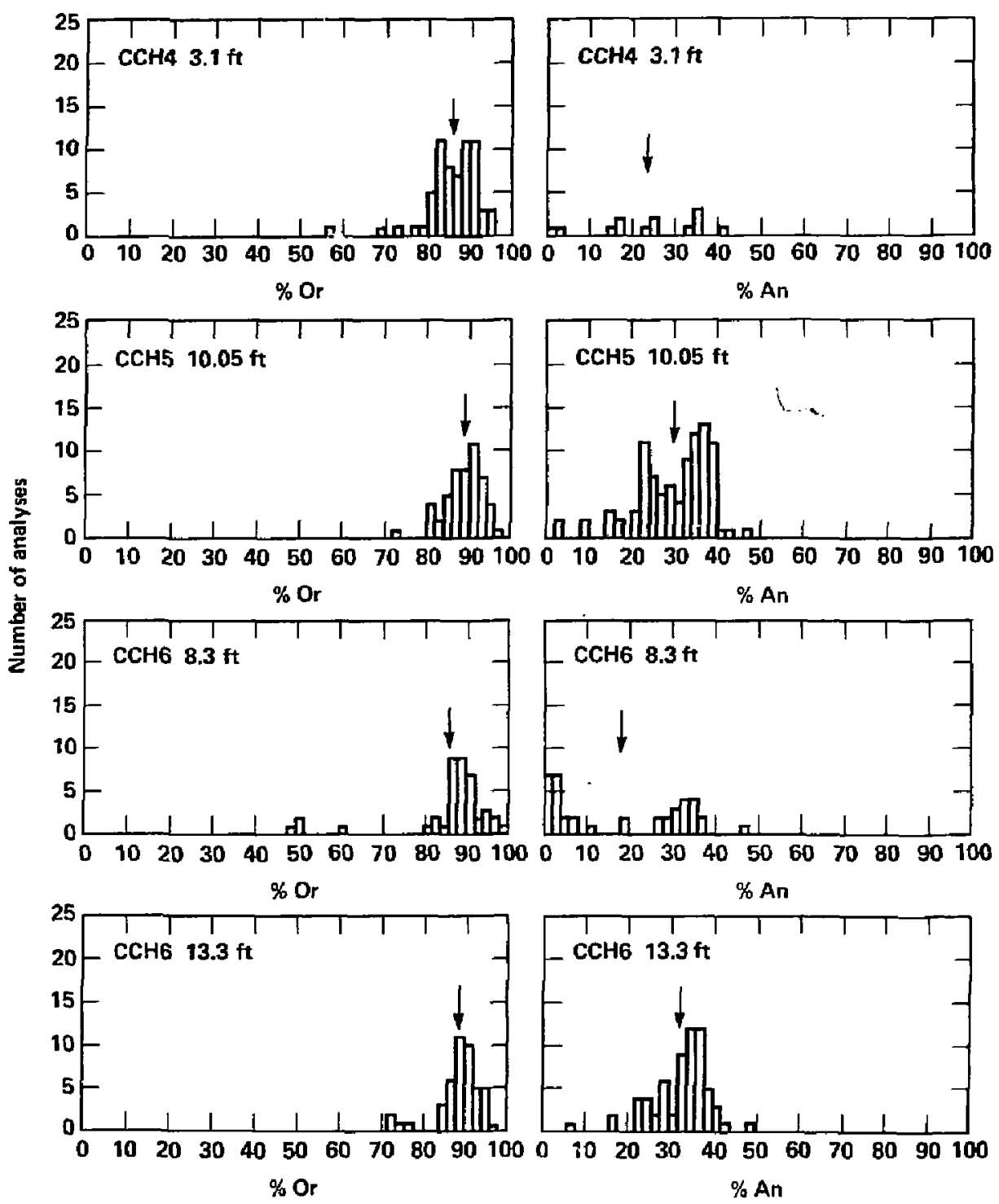

$\%$ An

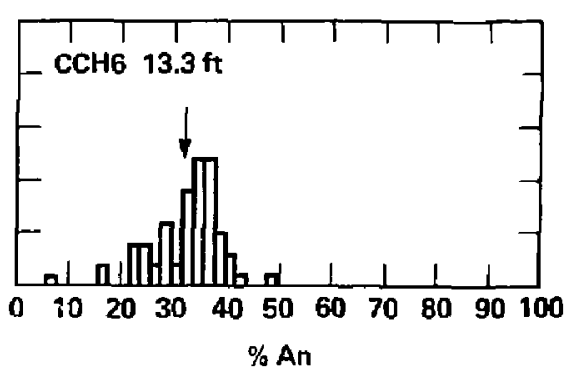

Fig. 6b. Histograms of feldspar analyses, arrows indicate average analysis, depth given in feet. 

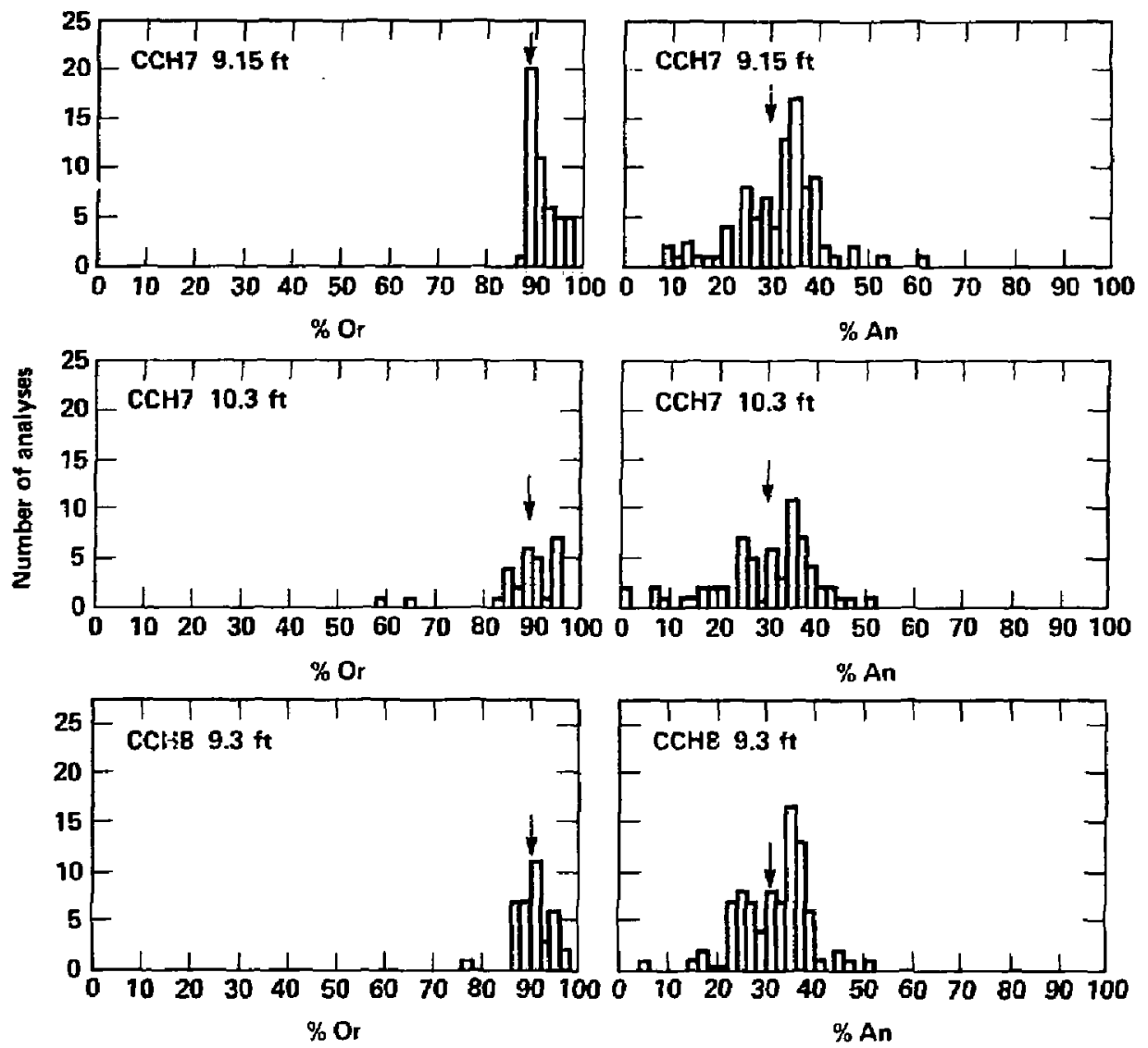

Fig. 6c. Histograms of feldspar analyses, arrows indicate average analysis, depth given in feet. 


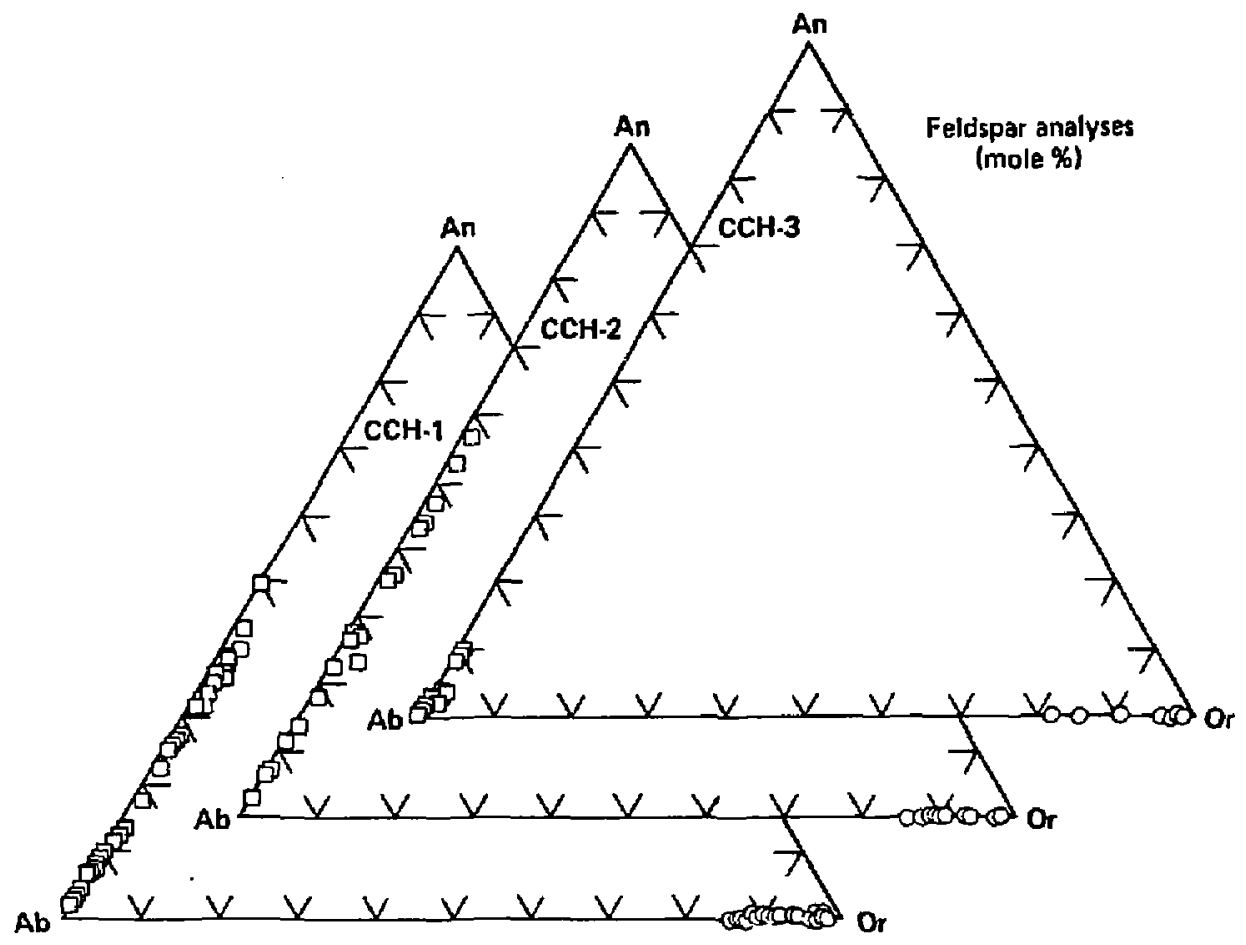

Fig. 7. Plats of feldspar analyses for $\mathrm{CCH}, 2$, and 3. Anaiyses obtained in interactive mode. 


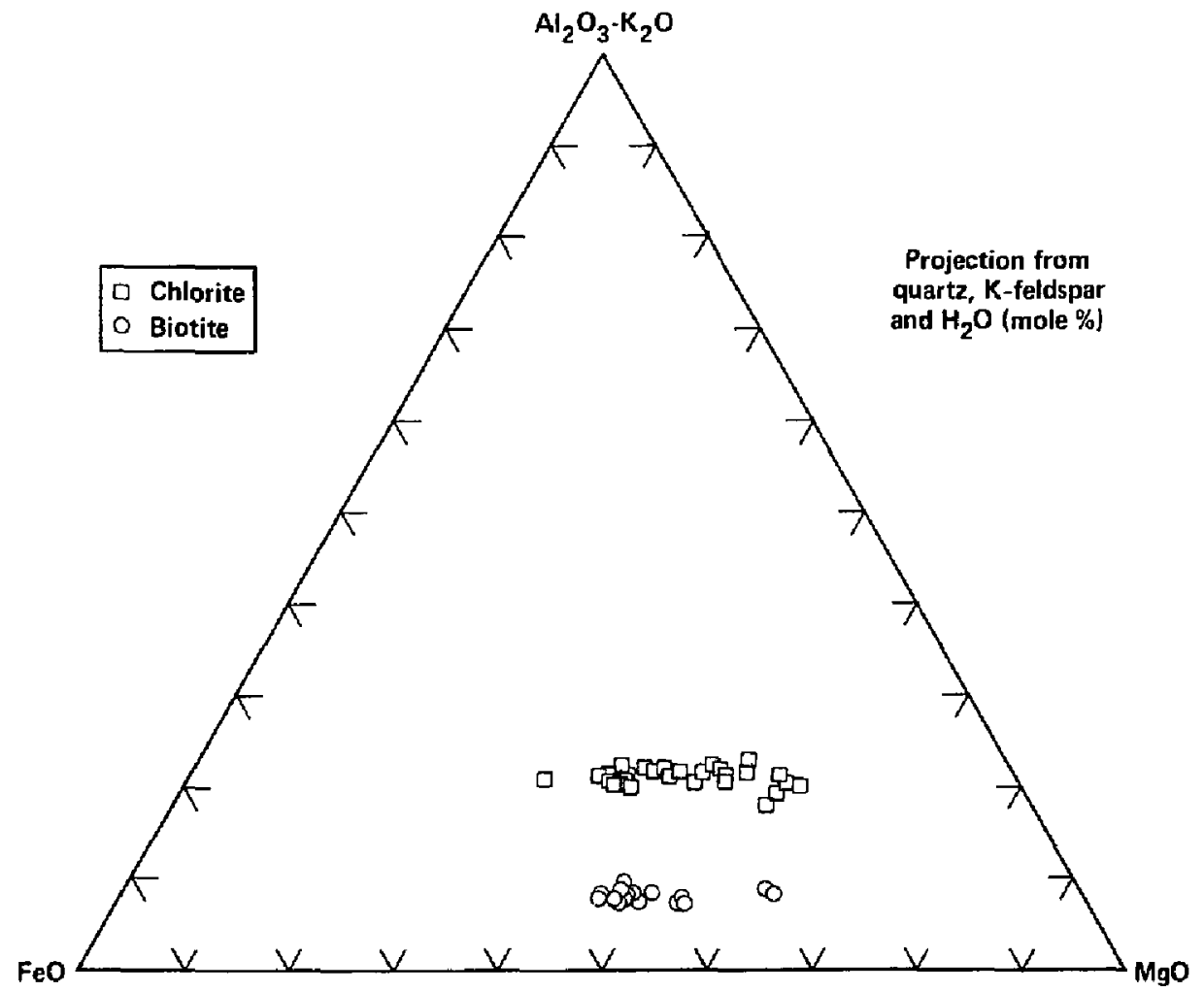

Fig. 8. Projection of biotite and chlorite analyses. 


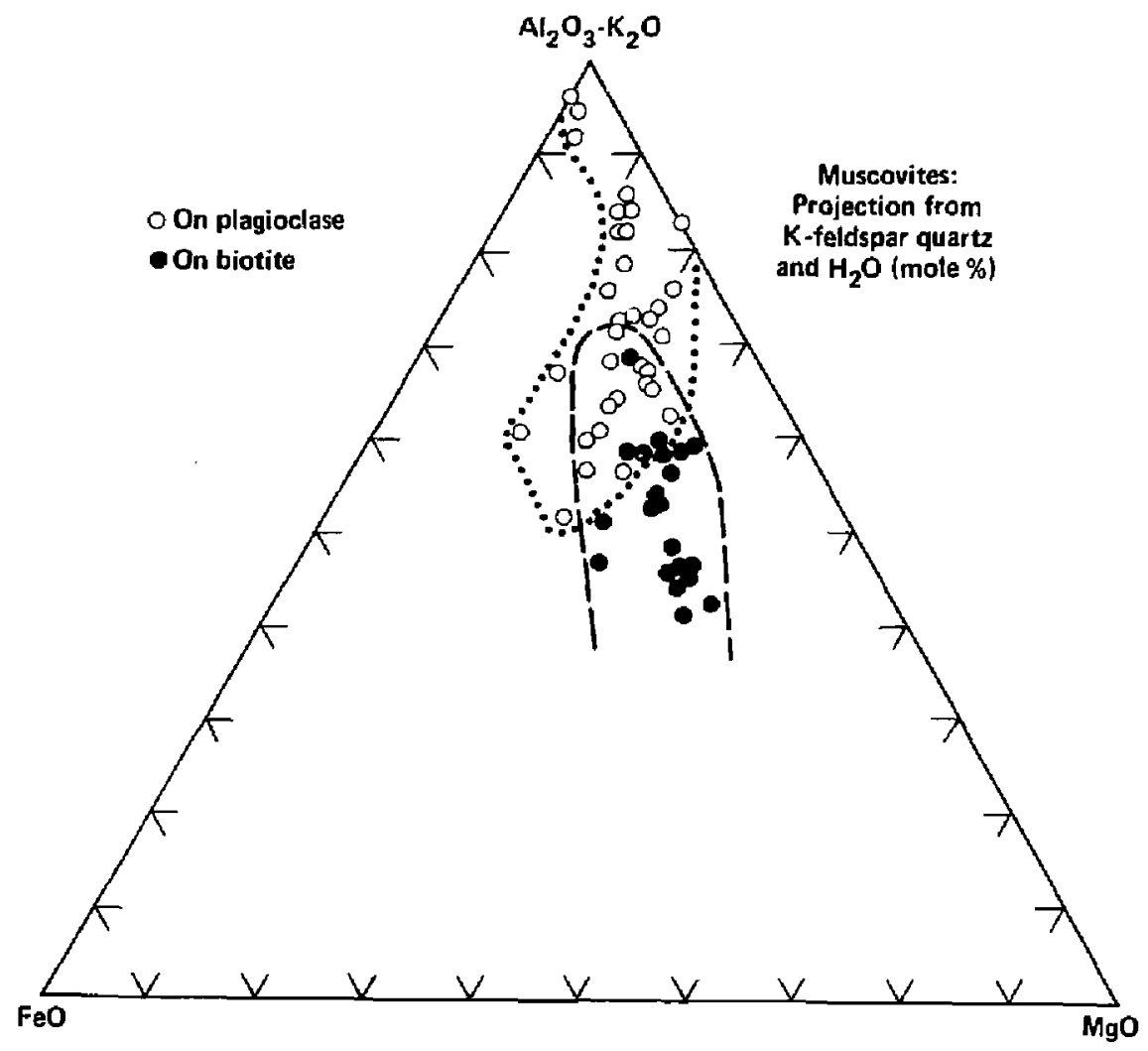

Fig. 9. Projection of muscovite analyses for grains found on biotite and plagioclase. 


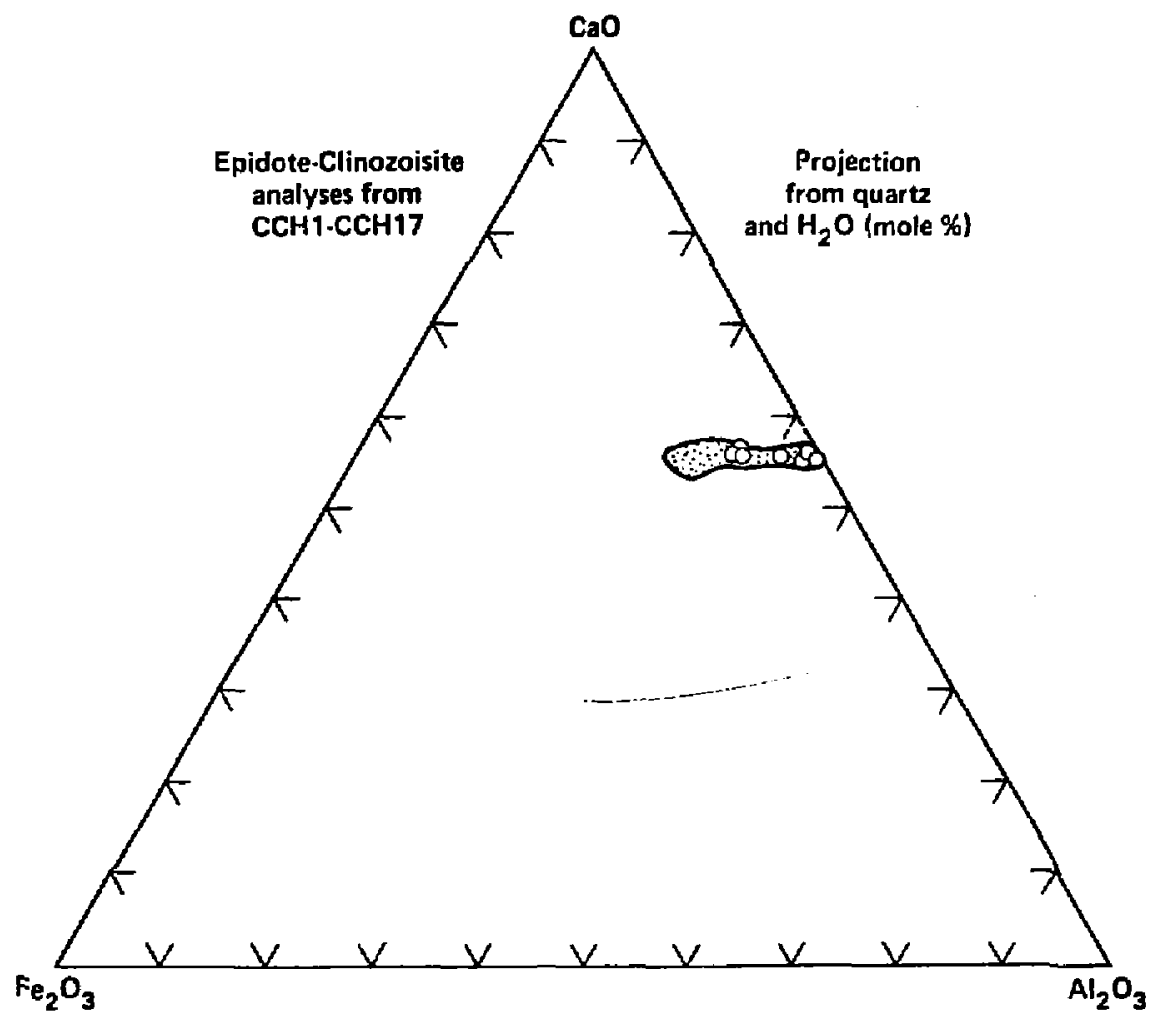

Fig. 10. Projection of epidote and clinozoisite analyses. The stippled field contains all the analyses. The open circles are from a single clinozosite grain included as a secondary phase in plagioclase (see text and Fig. 2) 
APPENDIX A

Secondary Mineral Assemblages

CCHI

\begin{tabular}{|c|c|c|c|c|c|c|c|c|c|c|c|c|c|c|c|c|c|c|}
\hline \multirow{2}{*}{\multicolumn{2}{|c|}{ DEPTH }} & \multicolumn{5}{|c|}{$P c$} & \multicolumn{3}{|c|}{$\mathrm{Kf}$} & \multicolumn{8}{|c|}{ Bt } & \\
\hline & & Pc & $k f$ & $\mathrm{Mu}$ & $E p$ & Cc & $\mathrm{kf}$ & Mu & CC & Bt & Chl & Mu & Ep & Tn & Ru & Cc & Py & \\
\hline 2.17 & $\begin{array}{l}H \\
S\end{array}$ & + & & + & + & + & + & + & & + & + & + & + & + & & & + & $\begin{array}{l}\text { A4 } \\
\text { El4 }\end{array}$ \\
\hline 2.45 & & + & & + & & 0 & + & & & + & + & & & & & & & 82 \\
\hline 2.78 & $\begin{array}{l}W \\
S\end{array}$ & + & & $\begin{array}{l}+ \\
+\end{array}$ & 0 & & + & & & + & + & D & + & + & & & & $\begin{array}{l}82 \\
014\end{array}$ \\
\hline 6.4 & $\begin{array}{l}W \\
S\end{array}$ & + & & + & & & + & & & + & + & + & + & + & & & + & $\begin{array}{l}82 \\
814\end{array}$ \\
\hline 6.75 & & + & & + & & + & + & & & & + & + & + & + & + & & + & 820 \\
\hline 8.75 & $\begin{array}{l}W \\
S\end{array}$ & + & & + & + & + & & & & + & + & + & + & + & + & & & $\begin{array}{l}\mathrm{Cl} 4 \\
010\end{array}$ \\
\hline 13.8 & $\begin{array}{l}H \\
5\end{array}$ & \pm & & + & & & + & + & + & + & $\begin{array}{l}+ \\
+\end{array}$ & $\begin{array}{l}+ \\
+\end{array}$ & & & & & & $\begin{array}{l}84 \\
84\end{array}$ \\
\hline 14.42 & & + & & + & & + & + & 0 & 0 & 0 & + & + & & + & + & & + & $\mathrm{C} 8$ \\
\hline 14.8 & & + & & + & & & + & & & + & + & + & + & + & & & $+d-$ & 89 \\
\hline 16.37 & & + & & + & 0 & 0 & + & & & & + & & + & + & + & & + & E18 \\
\hline 16.75 & & + & & + & & 0 & + & & & + & + & + & + & & & & + & C6 \\
\hline
\end{tabular}

+ indicates phase is present and common

0 indlcates phase is present, but only in minor amounts 
$\mathrm{CCH} 2$

\begin{tabular}{|c|c|c|c|c|c|c|c|c|c|c|c|c|c|c|c|c|c|c|}
\hline \multirow{2}{*}{\multicolumn{2}{|c|}{ DEPTH }} & \multicolumn{5}{|c|}{$P C$} & \multicolumn{3}{|c|}{$k f$} & \multicolumn{8}{|c|}{ Bt } & \\
\hline & & $\mathrm{PC}$ & $k f$ & $\mathrm{Mu}$ & $E p$ & $\mathrm{Cc}$ & $k f$ & Mu & $\mathrm{Cc}$ & Bt & Chl & Mu & Ep & Tn & Ru & $\mathrm{Cc}$ & Py & \\
\hline 3.35 & $\begin{array}{l}W \\
S\end{array}$ & + & & + & 0 & + & + & & & + & + & + & + & $\begin{array}{l}0 \\
+\end{array}$ & 0 & & & $\begin{array}{l}\mathrm{B} 1 \mathrm{l} \\
\mathrm{E} 24\end{array}$ \\
\hline 4.10 & & + & & + & & 0 & + & & & + & + & & + & + & & & & $\mathrm{C7}$ \\
\hline 6.82 & & & & & & & & & & & & & & & & & & \\
\hline 7.27 & $\begin{array}{l}W \\
5\end{array}$ & + & & + & & & + & & & + & + & & + & + & & & & $\begin{array}{l}\mathrm{B} 2 \\
\mathrm{Bl} 3\end{array}$ \\
\hline 7.6 & & + & & 0 & & & + & & & + & 0 & & & & & & & 62 \\
\hline 8.0 & & + & & 0 & & & & & & + & + & & + & & & & & B4 \\
\hline
\end{tabular}


CCH3

\begin{tabular}{|c|c|c|c|c|c|c|c|c|c|c|c|c|c|c|c|c|c|c|}
\hline \multirow[b]{2}{*}{ DEPTH } & & \multicolumn{5}{|c|}{$P c$} & \multicolumn{3}{|c|}{$k f$} & \multicolumn{8}{|c|}{ Bt } & \\
\hline & & PC & $k f$ & $\mathrm{Mu}$ & ED & CC & $k f$ & Mu & CC & Bt & Chl & Mu & Ep & In & Ru & Cc & $P y$ & \\
\hline 3.35 & $\begin{array}{l}W \\
S\end{array}$ & + & & + & & + & + & & & + & + & + & $\begin{array}{l}0 \\
+\end{array}$ & + & 0 & & & $\begin{array}{l}\mathrm{B7} \\
\mathrm{C} 20\end{array}$ \\
\hline 3.7 & & + & & + & & & + & & & + & + & & 0 & & & & & $B 4$ \\
\hline 8.9 & $\begin{array}{l}W \\
S\end{array}$ & + & & + & & + & + & & & + & + & + & 0 & + & & & + & $\begin{array}{l}\mathrm{B2} \\
\mathrm{Cl} 4\end{array}$ \\
\hline 9.15 & & + & & + & & & + & & & + & + & & + & & & & & $B 4$ \\
\hline 9.4 & & + & & 0 & & & + & & & + & 0 & & & & & & & $B 2$ \\
\hline 10.04 & $\begin{array}{l}W \\
S\end{array}$ & + & & + & + & & & & + & + & + & + & + & & & & $\begin{array}{l}\mathrm{O} 2 \\
\mathrm{E} 14\end{array}$ & \\
\hline 14.45 & & + & & $\begin{array}{l}0 \\
+\end{array}$ & & + & & & & + & + & + & & & + & + & + & $\begin{array}{l}\mathrm{B2} \\
\mathrm{Cl} 7\end{array}$ \\
\hline
\end{tabular}




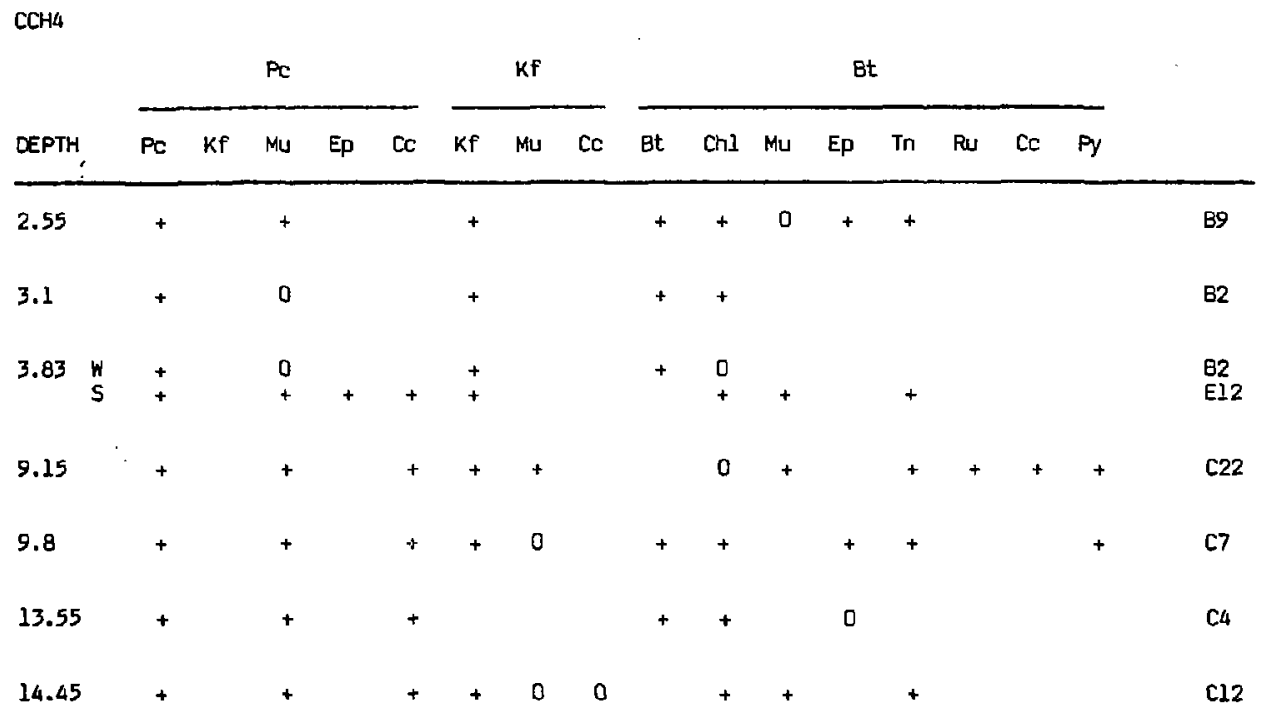


$\mathrm{CCH} 5$

\begin{tabular}{|c|c|c|c|c|c|c|c|c|c|c|c|c|c|c|c|c|c|c|}
\hline \multirow{2}{*}{\multicolumn{2}{|c|}{ DEPTH }} & \multicolumn{5}{|c|}{$P C$} & \multicolumn{3}{|c|}{$k f$} & \multicolumn{8}{|c|}{ Bt } & \\
\hline & & $\mathrm{PC}$ & $\mathrm{Kf}$ & Mu & Ep & $\mathrm{Cc}$ & $\mathrm{Kf}$ & $\mathrm{Mu}$ & $\mathrm{Cc}$ & $B t$ & Ch1 & Mu & Ep & Tn & $\mathrm{Ru}$ & CE & Py & \\
\hline 3.4 & & + & & + & & + & + & 0 & & & & + & + & + & & + & + & $\mathrm{C} 25$ \\
\hline 8.1 & & + & & + & & & + & & & + & + & & + & & & & & 84 \\
\hline 9.35 & $\begin{array}{l}W \\
S\end{array}$ & + & & $\begin{array}{l}0 \\
+\end{array}$ & & + & + & 0 & & + & + & 0 & + & + & & & + & $\begin{array}{l}\mathrm{B2} \\
\mathrm{Cl} 4\end{array}$ \\
\hline 10.05 & & + & & 0 & & & & & & + & + & & 0 & & & & & 84 \\
\hline 10.15 & & + & & + & & + & + & + & & & + & + & + & + & + & & + & $\mathrm{C} 20$ \\
\hline 10.2 & & + & & + & & 0 & + & + & & & + & & + & + & & & & $\mathrm{Cl} 3$ \\
\hline
\end{tabular}


CCH6

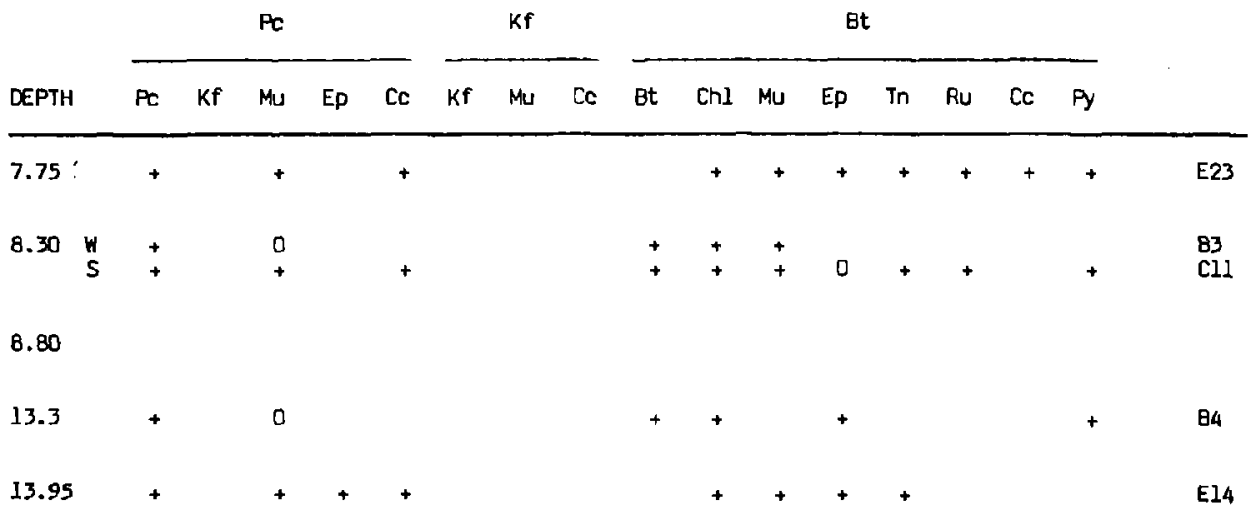


CCH7

Kf $\quad$ Bt

\begin{tabular}{|c|c|c|c|c|c|c|c|c|c|c|c|c|c|c|c|c|c|}
\hline \multirow{2}{*}{ DEPTH } & & & & \\
\hline & $P C$ & $K f$ & Mu & Ep & $C c$ & $k f$ & $M U$ & $\mathrm{Cc}$ & $B t$ & Chl & Mu & Ep & Tn & Ru & Cc & Py & \\
\hline \multicolumn{18}{|l|}{$9.15^{\circ}$} \\
\hline 9.57 & + & & + & & + & & & & & + & + & + & + & & + & + & E20 \\
\hline 10.3 & + & & 0 & & & & & & + & + & & 0 & & & & & 84 \\
\hline 10.65 & 4 & & 0 & & & & & & + & + & & 0 & & & & & $B 4$ \\
\hline $10.9 \quad H$ & + & & $\begin{array}{l}0 \\
+\end{array}$ & & + & & & & + & + & + & + & + & & & & $\begin{array}{l}\mathrm{B} 4 \\
\mathrm{Cl} 4\end{array}$ \\
\hline
\end{tabular}


$\mathrm{CCHB}$

\begin{tabular}{|c|c|c|c|c|c|c|c|c|c|c|c|c|c|c|c|c|c|c|}
\hline \multirow[b]{2}{*}{ DEPTH } & \multicolumn{5}{|c|}{$P c$} & \multicolumn{3}{|c|}{$\boldsymbol{k f}$} & \multicolumn{8}{|c|}{ Bt } & & \\
\hline & $P C$ & $k f$ & $\mathrm{Mu}$ & Ep & $\mathrm{Cc}$ & $\mathrm{Kf}$ & Mus & $\mathrm{CC}$ & Bt & Cnl & MU & $E D$ & Tn & Ru & Ce & Py & & \\
\hline $9.3:$ & + & + & & & & & & & + & + & . & & & & & + & & $\mathrm{B} 2$ \\
\hline 9.8 & + & & 0 & & & & & & + & + & & 0 & & & & + & & 84 \\
\hline 10.15 & + & & + & & + & + & & & & + & + & + & + & + & & + & * & $\mathrm{Cl} 9$ \\
\hline 10.55 & + & & + & & 0 & + & & & & + & + & + & + & & & + & & $\mathrm{Cl} 4$ \\
\hline
\end{tabular}


CCHO

\begin{tabular}{|c|c|c|c|c|c|c|c|c|c|c|c|c|c|c|c|c|c|c|}
\hline \multirow{2}{*}{\multicolumn{2}{|c|}{ DEPTH }} & \multicolumn{5}{|c|}{$\mathrm{PC}$} & \multicolumn{3}{|c|}{$k f$} & \multicolumn{8}{|c|}{ Bt } & \\
\hline & & $\mathrm{Pc}$ & $k f$ & MU & Ep & $c$ & $\mathrm{Kf}$ & $\mathrm{Mu}$ & Cc & Bt & Chl & $\mathrm{Mu}$ & Ep & Tn & Ru & CC & Py & \\
\hline 1.95 & $\begin{array}{l}W \\
S\end{array}$ & + & & $\begin{array}{l}0 \\
+\end{array}$ & & + & + & $D$ & & + & + & + & & + & & + & + & $\begin{array}{l}\mathrm{B2} \\
\mathrm{Cl} 6\end{array}$ \\
\hline 3.25 & $\begin{array}{l}W \\
S\end{array}$ & + & & $\begin{array}{l}0 \\
+\end{array}$ & & + & t & & & + & + & + & + & + & & & & $\begin{array}{l}\mathrm{B4} \\
\mathrm{Cl} 2\end{array}$ \\
\hline 3.6 & & + & & 0 & & & & & & + & + & & 0 & & & & + & 84 \\
\hline 8.2 & $\begin{array}{l}W \\
S\end{array}$ & + & & + & & + & & & & + & + & + & & + & + & & + & $\begin{array}{l}\text { 日2 } \\
\text { C15 }\end{array}$ \\
\hline 8.7 & & + & & 0 & & & & & & + & 0 & & & & & & & $B 2$ \\
\hline 9.4 & & + & & 0 & & & + & & & + & + & & & & & & + & $B 2$ \\
\hline 9.52 & & + & & + & 0 & & & & & + & + & & + & + & & & & 07 \\
\hline 14.47 & & + & & + & & + & + & & & & + & + & & + & + & + & + & Cl6 \\
\hline 14.75 & & + & & + & & & & & & + & + & & & & & & & 82 \\
\hline 14.97 & & + & & $\begin{array}{l}0 \\
+\end{array}$ & & + & & & & + & + & + & 0 & + & + & + & + & $\begin{array}{l}\mathrm{B} 4 \\
\mathrm{C} 22\end{array}$ \\
\hline
\end{tabular}

15.60 


\begin{tabular}{|c|c|c|c|c|c|c|c|c|c|c|c|c|c|c|c|c|c|}
\hline \multirow[b]{2}{*}{ DEPTH } & \multicolumn{5}{|c|}{ Pc } & \multicolumn{3}{|c|}{$k f$} & \multicolumn{8}{|c|}{ Bt } & \\
\hline & $\mathrm{Pc}$ & $\mathbf{K f}$ & Mu & Ep & Cc & $k f$ & Mu & $\mathrm{Cc}$ & Bt & $\mathrm{Chl}$ & Mu & Ep & Tn & Ru & $\mathrm{Cc}$ & $P y$ & \\
\hline 9.15 & + & & 0 & & & & & & + & + & & 0 & & & & + & 84 \\
\hline 9.75 & + & & 0 & & & + & & & + & + & & 0 & + & & & + & 87 \\
\hline 14.84 & + & & + & & + & & & & & + & + & & & + & + & + & $\mathrm{Cl7}$ \\
\hline $15.24 \underset{S}{W}$ & + & & $\begin{array}{l}0 \\
+\end{array}$ & & + & & & & + & $\begin{array}{l}+ \\
+\end{array}$ & + & & + & & & + & $\begin{array}{l}82 \\
\mathrm{C} 12\end{array}$ \\
\hline 15.38 & + & & + & & + & + & + & & & & + & & + & & & + & $\mathrm{C} 24$ \\
\hline
\end{tabular}


CCH1I

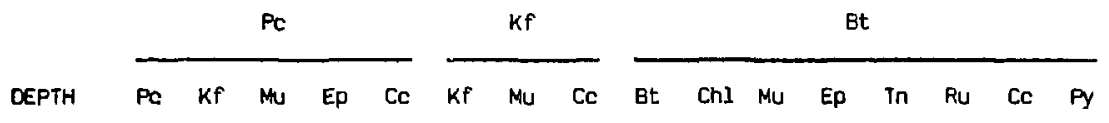

$9.5+0+++\quad B 2$

9.9

10.02 
CCH12

\begin{tabular}{|c|c|c|c|c|c|c|c|c|c|c|c|c|c|c|c|c|c|}
\hline \multirow[b]{2}{*}{ DEPTH } & \multicolumn{5}{|c|}{$P C$} & \multicolumn{3}{|c|}{$K \boldsymbol{F}$} & \multicolumn{8}{|c|}{ Bt } & \\
\hline & $P C$ & $k f$ & $m$ & Ep & $\mathrm{cc}$ & $K f$ & Mu & $\mathrm{Cc}$ & Bt & Chl & Mu & Ep & Tn & Ru & $\mathrm{Cc}$ & Py & \\
\hline 9.1 ! & + & & + & & + & + & & & & + & + & 0 & + & & + & + & $\mathrm{C} 21$ \\
\hline 9.35 & + & & 0 & & & + & & & & + & + & & + & & & + & $\mathrm{B} 12$ \\
\hline 9.70 & + & & + & & + & + & & & & 0 & + & & + & 0 & + & & $\mathrm{C} 22$ \\
\hline
\end{tabular}


CCH13

\begin{tabular}{|c|c|c|c|c|c|c|c|c|c|c|c|c|c|c|c|c|c|}
\hline \multirow[b]{2}{*}{ DEPTH } & \multicolumn{5}{|c|}{$\mathrm{Pc}$} & \multicolumn{3}{|c|}{$\mathrm{Kf}$} & \multicolumn{8}{|c|}{ Bt } & \\
\hline & $P_{C}$ & $k f$ & N.tu & Ep & $\mathrm{Cc}$ & $K f$ & MU & Cc & Bt & $C h 1$ & Mu & Ep & Tn & Ru & Cc & Py & \\
\hline $8.68 \underset{: S}{W}$ & + & & + & & & & & & + & + & + & + & & & & & $\begin{array}{l}\mathrm{B} 2 \\
\mathrm{~B} 22\end{array}$ \\
\hline 8.93 & + & & + & + & + & & & & & 0 & + & + & + & & & + & E14 \\
\hline 9.35 & + & & + & & + & + & & & & + & + & 0 & & + & 0 & & C21 \\
\hline 9.6 & + & & 0 & & & + & & & + & + & & 0 & & & & & 84 \\
\hline
\end{tabular}


CCHl 4

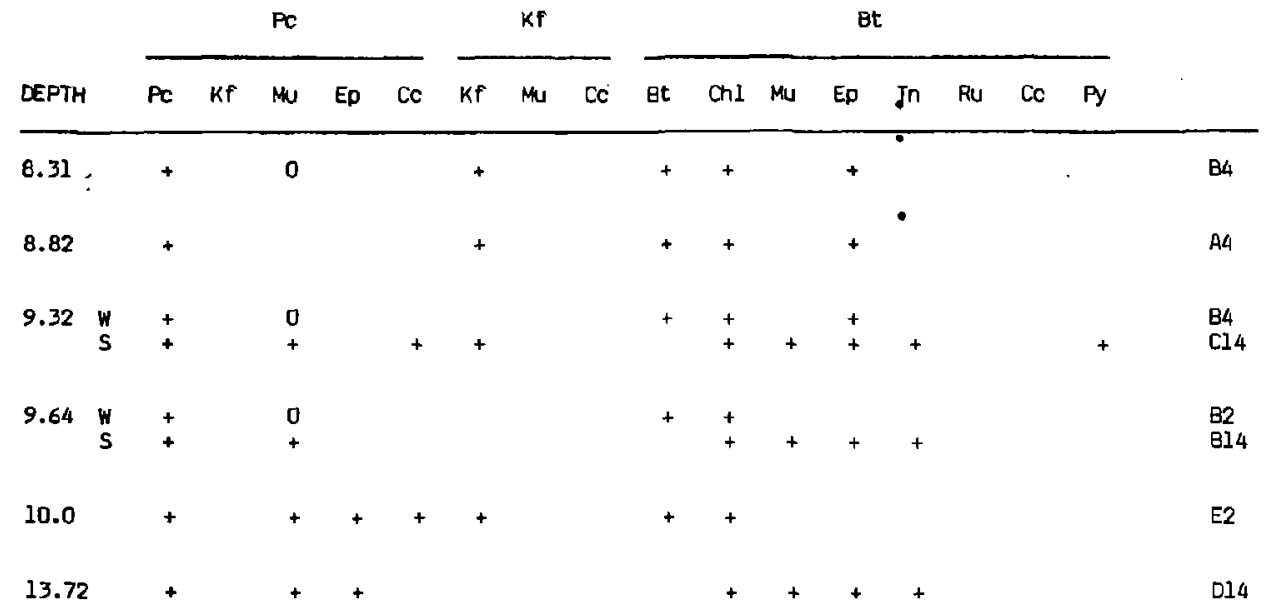




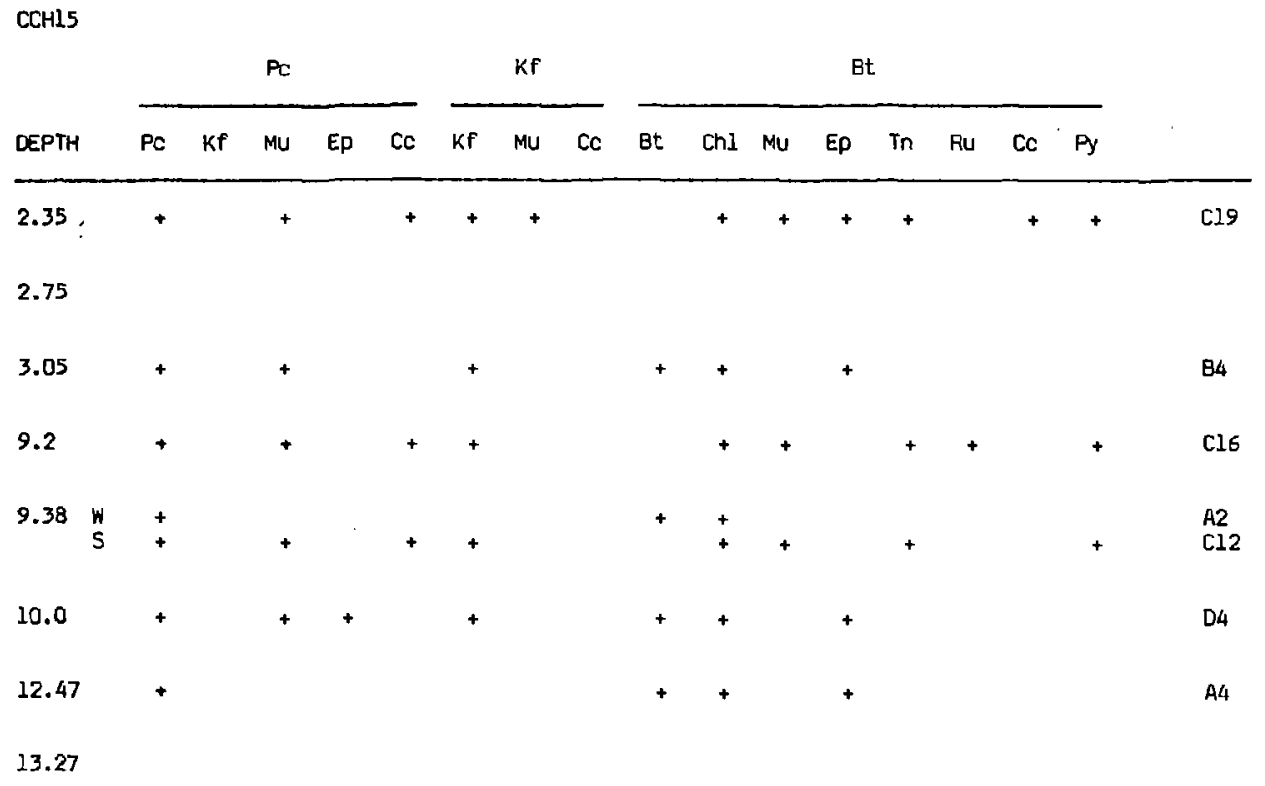




\section{$\mathrm{CCH} 16$}

\begin{tabular}{|c|c|c|c|c|c|c|c|c|c|c|c|c|c|c|c|c|c|}
\hline \multirow[b]{2}{*}{ DEPTH } & \multicolumn{5}{|c|}{$P E$} & \multicolumn{3}{|c|}{ Kf } & \multicolumn{8}{|c|}{ Bt } & \\
\hline & Pc & $K f$ & $\mathrm{Mu}$ & Ep & Cc & $\mathrm{Kf}$ & Mu & Cc & Bt & Chl & Mu & Ep & Tn & Ru & $C c$ & Py & \\
\hline $3.15^{\prime}$ & + & & + & & + & + & & & & & + & & + & & & + & C24 \\
\hline 3.75 & + & & + & & + & + & + & & & & + & 0 & + & & + & & C25 \\
\hline 9.05 & + & & & & & + & & & + & + & & & & & & & $A 2$ \\
\hline 9.3 & + & & + & & + & & & & & + & + & & & + & + & + & $\mathrm{C} 17$ \\
\hline 9.42 & + & & + & & + & + & & & & + & + & & & + & + & & $\mathrm{Cl} 7$ \\
\hline
\end{tabular}




\begin{tabular}{|c|c|c|c|c|c|c|c|c|c|c|c|c|c|c|c|c|c|}
\hline \multirow[b]{2}{*}{ DEPTH } & \multicolumn{5}{|c|}{$P C$} & \multicolumn{3}{|c|}{$\mathrm{Kf}$} & \multicolumn{8}{|c|}{ Bt } & \\
\hline & $\mathrm{PC}$ & $\mathrm{Kf}$ & Mu & Ep & Cc & $\mathrm{Kf}$ & Mu & Cc & Bt & Chl & Mu & Ep & Tn & Ru & Cc & Py & \\
\hline 7.45 & + & & & & & & & & + & + & & + & & & & & A4 \\
\hline 8.05 & + & & + & & & + & + & & 0 & + & & + & + & & & & B5 \\
\hline 8.2 & + & & + & & + & + & + & & & & + & & + & & & & C24 \\
\hline a. 25 & + & & + & & + & + & + & & & & + & & + & & & + & C24 \\
\hline 8.38 & + & & + & & & & & & & + & + & & + & & + & + & 815 \\
\hline 8.8 & + & & 0 & & & & & & + & + & & & + & & & & 85 \\
\hline 9.1 & + & & + & & + & & & & & + & + & & + & & & & $\mathrm{Cl} 2$ \\
\hline
\end{tabular}


APPENOIX 81

MODAL RNALYSES (VDL 7 ) OF CCHI SAMPLES SAMPLE DEPIH (FT.)

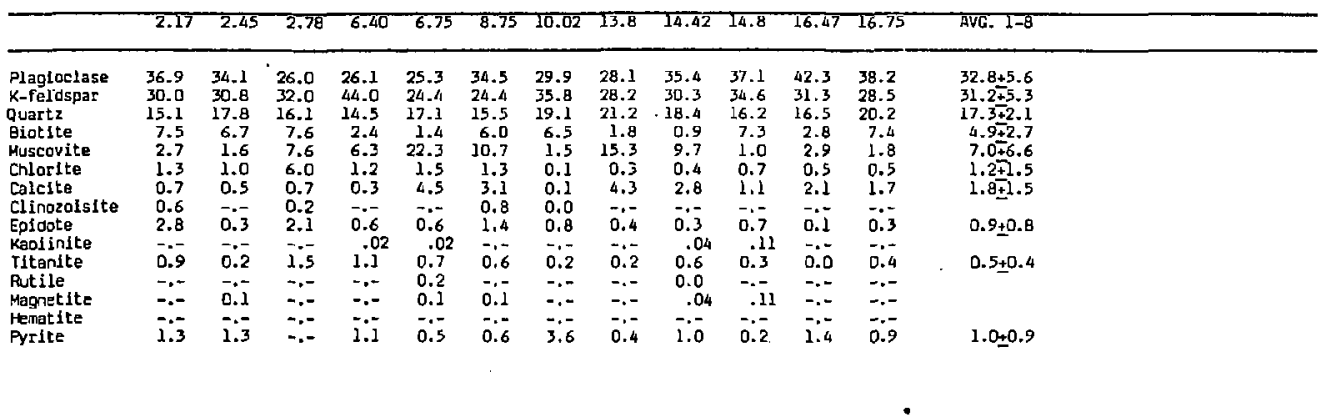



APPENOIX C

Microprobe Antyses of mineral phases

form the canistor control hole cores 
PLAGIOCLASE ANRLYSES

\begin{tabular}{|c|c|c|c|c|c|c|c|c|c|c|c|c|c|c|c|c|c|c|c|}
\hline ale $\theta$ & 1 & 1 & 1 & 1 & 1 & 1 & 1 & 1 & 1 & 1 & 1 & 1 & 1 & 1 & 1 & 1 & 1 & 1 & 1 \\
\hline epth & 2,17 & 2.17 & 2.17 & 2.17 & 2.17 & 2.17 & 2.17 & 2.17 & $2 . \overline{45}$ & 2,45 & 2.45 & 2.45 & 2.45 & 2.78 & 2.78 & 2.78 & 6.40 & 6.40 & 6.40 \\
\hline 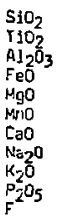 & $\begin{array}{r}59.28 \\
.00 \\
25.43 \\
.12 \\
.00 \\
.00 \\
6.44 \\
7.65 \\
.20 \\
.00 \\
.00\end{array}$ & $\begin{array}{r}61.15 \\
.00 \\
24.51 \\
.14 \\
.00 \\
.00 \\
5.03 \\
8.30 \\
.26 \\
.00 \\
.00\end{array}$ & $\begin{array}{r}58.68 \\
.02 \\
26.21 \\
.11 \\
.00 \\
.00 \\
7.30 \\
6.86 \\
.33 \\
.00 \\
.00\end{array}$ & $\begin{array}{r}63.88 \\
.00 \\
23.187 \\
.00 \\
.00 \\
.02 \\
2.91 \\
9.91 \\
.06 \\
.02 \\
.00\end{array}$ & $\begin{array}{r}59.51 \\
.00 \\
26.55 \\
.00 \\
.00 \\
.00 \\
7.16 \\
7.75 \\
.26 \\
.02 \\
.00\end{array}$ & $\begin{array}{r}58.05 \\
.00 \\
26.41 \\
.00 \\
.00 \\
.00 \\
7.97 \\
6.90 \\
.33 \\
.00 \\
.00\end{array}$ & $\begin{array}{r}61.23 \\
.03 \\
24.66 \\
.02 \\
.00 \\
.00 \\
5.35 \\
8.18 \\
.26 \\
.00 \\
.00\end{array}$ & $\begin{array}{r}58.54 \\
.03 \\
26.82 \\
.11 \\
.00 \\
.04 \\
7.36 \\
7.01 \\
.24 \\
.00 \\
.00\end{array}$ & $\begin{array}{r}57.38 \\
.00 \\
28.35 \\
.12 \\
.00 \\
.04 \\
8.96 \\
6.38 \\
.19 \\
.04 \\
.00\end{array}$ & $\begin{array}{r}61.45 \\
.00 \\
24.83 \\
.00 \\
.00 \\
.00 \\
5.37 \\
8.47 \\
.26 \\
.11 \\
.00\end{array}$ & $\begin{array}{r}62.64 \\
.01 \\
25.07 \\
.15 \\
.00 \\
.04 \\
5.17 \\
8.48 \\
.26 \\
.00 \\
.00\end{array}$ & $\begin{array}{r}58.72 \\
.00 \\
27.20 \\
.00 \\
.00 \\
.00 \\
8.04 \\
6.45 \\
.40 \\
.00 \\
.00\end{array}$ & $\begin{array}{r}56.46 \\
.10 \\
28.60 \\
.00 \\
.00 \\
.00 \\
9.87 \\
5.60 \\
.11 \\
.00 \\
.00\end{array}$ & $\begin{array}{r}66.03 \\
.00 \\
20.11 \\
.02 \\
.00 \\
.00 \\
.34 \\
10.90 \\
.05 \\
.00 \\
.00\end{array}$ & $\begin{array}{r}68.26 \\
.00 \\
20.36 \\
.02 \\
.00 \\
.00 \\
.45 \\
11.36 \\
.04 \\
.00 \\
.00\end{array}$ & $\begin{array}{r}67.18 \\
.00 \\
22.18 \\
.00 \\
.00 \\
.00 \\
1.98 \\
10.95 \\
.04 \\
.00 \\
.00\end{array}$ & $\begin{array}{r}61.42 \\
.00 \\
25.16 \\
.21 \\
.00 \\
.00 \\
5.62 \\
8.07 \\
.25 \\
.00 \\
.00\end{array}$ & $\begin{array}{r}67.45 \\
.00 \\
21.53 \\
.02 \\
.00 \\
.00 \\
1.34 \\
10.69 \\
.06 \\
.00 \\
.00\end{array}$ & $\begin{array}{r}65.28 \\
.00 \\
22.18 \\
.05 \\
.00 \\
.00 \\
2.49 \\
10.21 \\
.00 \\
.00 \\
.00\end{array}$ \\
\hline
\end{tabular}

TOTAL $\quad 99.19 \quad 99.39 \quad 99.52 \quad 99.97 \quad 101.24 \quad 99.65 \quad 99.73 \quad 99.81 \quad 101.44 \quad 100.67 \quad 101.63 \quad 101.20 \quad 00.74 \quad 97.50100 .50 \quad 102.33 \quad 100.80 \quad 101.09 \quad 100.31$

\section{PLAGIOCLASE ANALYSES}

\begin{tabular}{|c|c|c|c|c|c|c|c|c|c|c|c|c|c|c|c|c|c|c|c|}
\hline ole & 1 & 1 & 1 & 1 & 1 & 1 & 1 & 1 & 1 & 1 & 2 & 2 & 2 & 2 & 2 & 2 & 2 & 2 & 2 \\
\hline Depth & 6.40 & 5.75 & 6.75 & 6.75 & 6.75 & 6.75 & 13.8 & 14.42 & $1 \overline{6} .47$ & 16.47 & 6.87 & 6.87 & 6.87 & 7.27 & $7.2 ?$ & 7.27 & 7.27 & 7.27 & 7.27 \\
\hline $\begin{array}{l}\mathrm{S}_{10} \\
\mathrm{~T}_{2} \\
\mathrm{Al}_{2} \mathrm{O}_{3} \\
\mathrm{FeO} \\
\mathrm{MgO} \\
\mathrm{MnO} \\
\mathrm{CaO} \\
\mathrm{Na}_{2} \mathrm{O} \\
\mathrm{K}_{2} \mathrm{O} \\
\mathrm{P}_{2} \mathrm{O}_{5} \\
\mathrm{~F}^{2} \mathrm{~S}^{2}\end{array}$ & $\begin{array}{r}65.74 \\
.28 \\
22.49 \\
.04 \\
.00 \\
.00 \\
2.69 \\
10.13 \\
.06 \\
.00 \\
.00\end{array}$ & $\begin{array}{r}59.22 \\
.01 \\
25.84 \\
.16 \\
.00 \\
.05 \\
7.27 \\
7.00 \\
.26 \\
.00 \\
.00\end{array}$ & $\begin{array}{r}59.55 \\
.04 \\
26.42 \\
.12 \\
.00 \\
.01 \\
7.27 \\
7.30 \\
.20 \\
.00 \\
.00\end{array}$ & $\begin{array}{r}59.32 \\
.00 \\
26.54 \\
.30 \\
.00 \\
.00 \\
6.96 \\
7.49 \\
.28 \\
.02 \\
.00\end{array}$ & $\begin{array}{r}66.01 \\
.00 \\
21.57 \\
.03 \\
.00 \\
.00 \\
1.69 \\
10.33 \\
.11 \\
.02 \\
.00\end{array}$ & $\begin{array}{r}67.31 \\
.00 \\
20.87 \\
.02 \\
.00 \\
.01 \\
.81 \\
10.72 \\
.09 \\
.00 \\
.00\end{array}$ & $\begin{array}{r}67.89 \\
.00 \\
20.63 \\
.00 \\
.00 \\
.02 \\
.40 \\
11.66 \\
.16 \\
.00 \\
.00\end{array}$ & $\begin{array}{r}69.43 \\
.00 \\
20.94 \\
.00 \\
.00 \\
.00 \\
.13 \\
11.67 \\
.07 \\
.00 \\
.00\end{array}$ & $\begin{array}{r}61.00 \\
.00 \\
25.59 \\
.12 \\
.00 \\
.04 \\
6.64 \\
7.76 \\
.30 \\
.04 \\
.00\end{array}$ & $\begin{array}{r}60.50 \\
.00 \\
26.91 \\
.11 \\
.00 \\
.01 \\
6.87 \\
7.53 \\
.16 \\
.11 \\
.00\end{array}$ & $\begin{array}{r}69.15 \\
.03 \\
20.75 \\
.12 \\
.00 \\
.02 \\
.61 \\
11.12 \\
.00 \\
.00 \\
.00\end{array}$ & $\begin{array}{r}63.64 \\
.00 \\
24.33 \\
.00 \\
.01 \\
.00 \\
4.59 \\
8.90 \\
.14 \\
.00 \\
.00\end{array}$ & $\begin{array}{r}60.76 \\
.00 \\
25.67 \\
.12 \\
.07 \\
.04 \\
5.48 \\
8.38 \\
.18 \\
.00 \\
.00\end{array}$ & $\begin{array}{r}67.47 \\
.03 \\
22.26 \\
.02 \\
.00 \\
.00 \\
1.41 \\
10.70 \\
.08 \\
.00 \\
.00\end{array}$ & $\begin{array}{r}66.90 \\
.00 \\
21.21 \\
.02 \\
.00 \\
.01 \\
1.28 \\
10.72 \\
.03 \\
.00 \\
.00\end{array}$ & $\begin{array}{r}63.02 \\
.05 \\
23.56 \\
.00 \\
.00 \\
.02 \\
3.95 \\
9.55 \\
.14 \\
.00 \\
.00\end{array}$ & $\begin{array}{r}53.59 \\
.02 \\
30.73 \\
.20 \\
.19 \\
.00 \\
11.50 \\
4.82 \\
.23 \\
.00 \\
.00\end{array}$ & $\begin{array}{r}56.07 \\
.00 \\
28.77 \\
.14 \\
.00 \\
.00 \\
9.86 \\
5.98 \\
.23 \\
.00 \\
.00\end{array}$ & $\begin{array}{r}54.25 \\
.42 \\
29.14 \\
.18 \\
.00 \\
.4 \\
10.78 \\
5.20 \\
.25 \\
.60 \\
.60\end{array}$ \\
\hline
\end{tabular}

TOTAL $101.44 \quad 100.81 \quad 100.91 \quad 100.89 \quad 99.72 \quad 99.84 \quad 100.78 \quad 102.25 \quad 101.43 \quad 102.10100 .80 \quad 101.68100 .65101 .97 \quad 100.18 \quad 101.08 \quad 101.28101 .06100 .26$ 
PLACIOCLASE ANALYSES

\begin{tabular}{|c|c|c|c|c|c|c|c|c|c|c|c|c|c|c|c|c|c|c|c|}
\hline tole & 2 & 2 & 2 & 2 & 2 & 2 & 2 & 2 & 2 & 3 & 3 & 3 & 3 & 3 & 3 & 3 & 3 & 3 & 3 \\
\hline Depth & 7.27 & 8.00 & 8.00 & 8.00 & 8.00 & 8.00 & 8.00 & 8.00 & 8.00 & 3.03 & 3.83 & 3,83 & 3.83 & 3.83 & 3.83 & 3.83 & 6.90 & 8.90 & 8.90 \\
\hline $\begin{array}{l}\mathrm{S1O}_{2} \\
\mathrm{~T}_{2} \mathrm{O}_{3} \\
\mathrm{~S}_{2} \mathrm{O}_{3} \\
\mathrm{FeO} \\
\mathrm{MgO} \\
\mathrm{MnO} \\
\mathrm{CaO} \\
\mathrm{Na}_{2} \mathrm{O} \\
\mathrm{K}_{2} \mathrm{O} \\
\mathrm{P}_{2} \mathrm{O}_{5} \\
\mathrm{~F}^{2}\end{array}$ & $\begin{array}{r}59.09 \\
.00 \\
26.36 \\
.21 \\
.00 \\
.02 \\
7.37 \\
7.26 \\
.29 \\
.00 \\
.00\end{array}$ & $\begin{array}{r}66.00 \\
.00 \\
22.02 \\
.00 \\
.00 \\
.00 \\
2.30 \\
10.17 \\
.10 \\
.00 \\
.00\end{array}$ & $\begin{array}{r}61.69 \\
.25 .08 \\
.21 \\
.02 \\
.00 \\
5.59 \\
8.22 \\
.37 \\
.00 \\
.00\end{array}$ & $\begin{array}{r}60.68 \\
.00 \\
24.68 \\
.17 \\
.00 \\
.00 \\
5.54 \\
8.10 \\
.31 \\
.00 \\
.00\end{array}$ & $\begin{array}{r}58.02 \\
.00 \\
25.78 \\
.15 \\
.00 \\
.04 \\
7.29 \\
7.20 \\
.19 \\
.00 \\
.00\end{array}$ & $\begin{array}{r}57.25 \\
.14 \\
7.69 \\
.19 \\
.00 \\
.00 \\
8.63 \\
6.00 \\
.19 \\
.00 \\
.00\end{array}$ & $\begin{array}{r}57.86 \\
.04 \\
28.00 \\
.75 \\
.00 \\
.02 \\
8.59 \\
6.01 \\
.19 \\
.00 \\
.00\end{array}$ & $\begin{array}{r}65.50 \\
.00 \\
22.64 \\
.03 \\
.00 \\
.03 \\
2.78 \\
9.86 \\
.14 \\
.00 \\
.00\end{array}$ & $\begin{array}{r}61.96 \\
.08 \\
25.70 \\
.03 \\
.00 \\
.50 \\
4.85 \\
8.47 \\
.57 \\
.00 \\
.00\end{array}$ & $\begin{array}{r}66.62 \\
.13 \\
22.31 \\
.19 \\
.00 \\
.00 \\
1.82 \\
10.64 \\
.14 \\
.00 \\
.00\end{array}$ & $\begin{array}{r}65.99 \\
.00 \\
22.32 \\
.10 \\
.00 \\
.04 \\
1.65 \\
10.65 \\
.07 \\
.00 \\
.00\end{array}$ & $\begin{array}{r}68.59 \\
.14 \\
20.92 \\
.00 \\
.00 \\
.00 \\
.56 \\
11.69 \\
.03 \\
.00 \\
.00\end{array}$ & $\begin{array}{r}68.14 \\
.00 \\
20.72 \\
.05 \\
.00 \\
.00 \\
.59 \\
11.36 \\
.04 \\
.00 \\
.00\end{array}$ & $\begin{array}{r}68.76 \\
.15 \\
20.98 \\
.03 \\
.00 \\
.00 \\
.73 \\
11.41 \\
.03 \\
.00 \\
.00\end{array}$ & $\begin{array}{r}68.40 \\
.00 \\
21.27 \\
.02 \\
.00 \\
.00 \\
.69 \\
11.18 \\
.22 \\
.00 \\
.00\end{array}$ & $\begin{array}{r}67.51 \\
.23 \\
21.04 \\
.00 \\
.00 \\
.00 \\
.83 \\
11.34 \\
.16 \\
.00 \\
.00\end{array}$ & $\begin{array}{r}68.71 \\
.00 \\
20.00 \\
.00 \\
.00 \\
.00 \\
.49 \\
11.39 \\
.00 \\
.00 \\
.00\end{array}$ & $\begin{array}{r}67.44 \\
.00 \\
20.90 \\
.00 \\
.00 \\
.00 \\
.73 \\
11.05 \\
.11 \\
.00 \\
.00\end{array}$ & $\begin{array}{r}68.25 \\
.00 \\
20.62 \\
.00 \\
.00 \\
.00 \\
.34 \\
11.63 \\
.09 \\
.00 \\
.00\end{array}$ \\
\hline
\end{tabular}

TataL $100.65100 .60101 .47 \quad 99.48 \quad 100.46100 .13101 .44100 .98 \quad 102.16101 .85100 .77101 .92100 .89102 .08 \quad 101.77101 .18101 .55100 .29100 .94$

\section{PLAGIOCLASE ANALYSES}

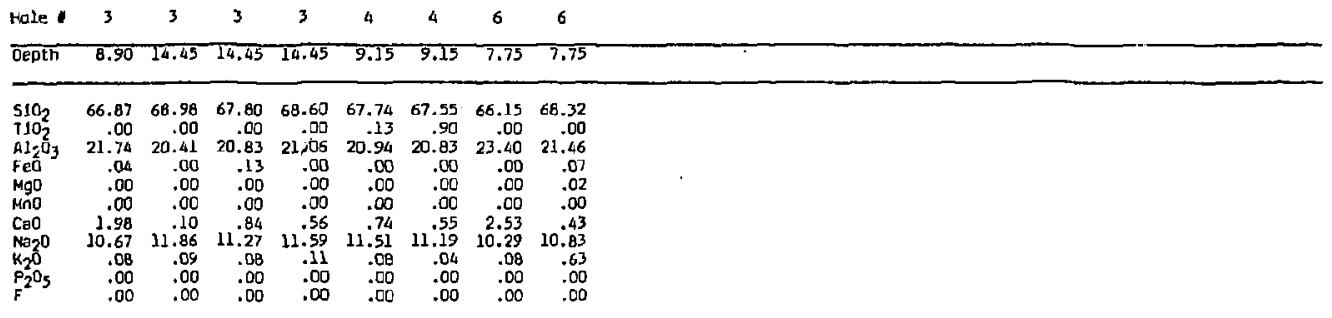

IOTAL $101.14 \quad 101.44 \quad 100.94 \quad 101.92 \quad 101.14 \quad 100.25102 .45101 .76$ 
K-FELDSPAR ANALYSES

\begin{tabular}{|c|c|c|c|c|c|c|c|c|c|c|c|c|c|c|c|c|c|c|c|}
\hline Hole & 1 & 1 & 1 & 1 & 1 & 1 & 1 & 1 & 1 & 1 & 1 & 1 & 1 & 1 & 1 & 1 & 1 & 1 & 1 \\
\hline Depth & 2.17 & 2.17 & 2.17 & 2.45 & 2.45 & 2.45 & 2.45 & 7.78 & 2.78 & 6.40 & 6.40 & 5.40 & $\overline{6} .40$ & 6.40 & 6.40 & 6.75 & 6.75 & 6.75 & 6.75 \\
\hline $\begin{array}{l}\mathrm{S}_{10} \\
\mathrm{TiO}_{2} \\
\mathrm{Al}_{2} \mathrm{O}_{3} \\
\mathrm{FeO} \\
\mathrm{MgO} \\
\mathrm{MnO} \\
\mathrm{CaO} \\
\mathrm{Na}_{2} \mathrm{O} \\
\mathrm{K}_{2} \mathrm{O} \\
\mathrm{P}_{2} \mathrm{O}_{5} \\
\mathrm{~F}^{2}\end{array}$ & $\begin{array}{r}64.02 \\
.03 \\
19.16 \\
.06 \\
.00 \\
.00 \\
.00 \\
1.28 \\
14.95 \\
.00 \\
.00\end{array}$ & $\begin{array}{r}64.00 \\
.39 \\
19.29 \\
.08 \\
.00 \\
.00 \\
.03 \\
.99 \\
15.58 \\
.00 \\
.00\end{array}$ & $\begin{array}{r}64.41 \\
.00 \\
19.13 \\
.00 \\
.00 \\
.00 \\
.00 \\
1.10 \\
15.22 \\
.13 \\
.00\end{array}$ & $\begin{array}{r}65.25 \\
.00 \\
19.71 \\
.06 \\
.00 \\
.01 \\
.11 \\
1.58 \\
24.25 \\
.11 \\
.00\end{array}$ & $\begin{array}{r}65.34 \\
.00 \\
19.22 \\
.05 \\
.00 \\
.00 \\
.00 \\
1.38 \\
14.92 \\
.00 \\
.00\end{array}$ & $\begin{array}{r}65.11 \\
.01 \\
19.37 \\
.03 \\
.00 \\
.02 \\
.02 \\
1.18 \\
15.32 \\
.00 \\
.00\end{array}$ & $\begin{array}{r}66.47 \\
.00 \\
19.07 \\
.11 \\
.00 \\
.00 \\
.00 \\
1.22 \\
15.14 \\
.00 \\
.00\end{array}$ & $\begin{array}{r}65.28 \\
.00 \\
19.75 \\
.05 \\
.00 \\
.04 \\
.08 \\
1.50 \\
14.92 \\
.00 \\
.00\end{array}$ & $\begin{array}{r}615.10 \\
100 \\
19.02 \\
.04 \\
.00 \\
.04 \\
.04 \\
1.25 \\
15.44 \\
.09 \\
.00\end{array}$ & $\begin{array}{r}65.02 \\
.01 \\
19.50 \\
.08 \\
.00 \\
.00 \\
.08 \\
1.41 \\
14.38 \\
.04 \\
.00\end{array}$ & $\begin{array}{r}64.80 \\
.00 \\
19.41 \\
.05 \\
.00 \\
.00 \\
.06 \\
1.25 \\
14.59 \\
.00 \\
.00\end{array}$ & $\begin{array}{r}65.26 \\
.00 \\
19.73 \\
.00 \\
.00 \\
.07 \\
.02 \\
.98 \\
15.27 \\
.05 \\
.00\end{array}$ & $\begin{array}{r}64.70 \\
.00 \\
19.13 \\
.08 \\
.00 \\
.03 \\
.00 \\
.99 \\
15.15 \\
.00 \\
.00\end{array}$ & $\begin{array}{r}65.46 \\
.02 \\
18.91 \\
.09 \\
.00 \\
.04 \\
.03 \\
1.11 \\
15.52 \\
.00 \\
.00\end{array}$ & $\begin{array}{r}64.67 \\
19.06 \\
19.23 \\
.04 \\
.00 \\
.00 \\
.03 \\
.36 \\
15.96 \\
.00 \\
.00\end{array}$ & $\begin{array}{r}65.53 \\
.00 \\
18.62 \\
.07 \\
.00 \\
.00 \\
.01 \\
1.11 \\
15.30 \\
.00 \\
.00\end{array}$ & $\begin{array}{r}64.61 \\
.05 \\
20.00 \\
.03 \\
.00 \\
.00 \\
.02 \\
.29 \\
16.32 \\
.00 \\
.00\end{array}$ & $\begin{array}{r}64.52 \\
.00 \\
19.44 \\
.05 \\
.00 \\
.01 \\
.00 \\
.61 \\
16.13 \\
.00 \\
.00\end{array}$ & $\begin{array}{r}64.54 \\
18.77 \\
.06 \\
.00 \\
.00 \\
.02 \\
.35 \\
16.25 \\
.00 \\
.00\end{array}$ \\
\hline
\end{tabular}

TOTAL $99.55100 .34 \quad 99.99101 .09100 .90101 .06 \quad 102.01 \quad 101.67100 .98 \quad 100.60100 .16 \quad 201.36100 .08101 .16100 .34100 .64101 .32 \quad 100.78 \quad 99.99$

\section{H-FELDSPAR ANALYSES}

\begin{tabular}{|c|c|c|c|c|c|c|c|c|c|c|c|c|c|c|c|c|c|c|c|}
\hline ble & 1 & 1 & 1 & 1 & 1 & 1 & 1 & 1 & 2 & 1 & 1 & 1 & 1 & 1 & 1 & 1 & 1 & 2 & 2 \\
\hline Depth & 6.40 & 6.75 & 6.75 & 6.75 & 6.75 & 6.75 & 13.80 & $14 . \overline{22}$ & 16.47 & 16.47 & 16.47 & $\sqrt{6.47}$ & 16.47 & 16.47 & 16,47 & 16,47 & 16.47 & 6.87 & 6.87 \\
\hline $\begin{array}{l}\mathrm{SIO}_{2} \\
\mathrm{1LO}_{2} \\
\mathrm{Al}_{2} \mathrm{O}_{3} \\
\mathrm{FEO} \\
\mathrm{MgO} \\
\mathrm{MnO} \\
\mathrm{CaO} \\
\mathrm{Na}_{2} \mathrm{O} \\
\mathrm{K}_{2} \mathrm{O} \\
\mathrm{P}_{2} \mathrm{O}_{5} \\
\mathrm{~F}\end{array}$ & $\begin{array}{r}64.90 \\
.06 \\
19.33 \\
.02 \\
.03 \\
.00 \\
.07 \\
1.13 \\
14.95 \\
.00 \\
.00\end{array}$ & $\begin{array}{r}64.61 \\
.05 \\
20.00 \\
.03 \\
.00 \\
.00 \\
.02 \\
.029 \\
16.32 \\
.00 \\
.00\end{array}$ & $\begin{array}{r}64.52 \\
.00 \\
29.40 \\
.05 \\
.00 \\
.01 \\
.00 \\
.61 \\
16.13 \\
.00 \\
.00\end{array}$ & $\begin{array}{r}64.54 \\
18.00 \\
.06 \\
.00 \\
.00 \\
.02 \\
.35 \\
16.25 \\
.00 \\
.00\end{array}$ & $\begin{array}{r}64.90 \\
.06 \\
19.33 \\
.02 \\
.03 \\
.00 \\
.07 \\
1.13 \\
14.95 \\
.00 \\
.00\end{array}$ & $\begin{array}{r}63.56 \\
.03 \\
19.10 \\
.00 \\
.04 \\
.00 \\
.00 \\
.40 \\
16.20 \\
.06 \\
.00\end{array}$ & $\begin{array}{r}63.19 \\
.00 \\
18.67 \\
.00 \\
.00 \\
.03 \\
.00 \\
.39 \\
16.26 \\
.00 \\
.00\end{array}$ & $\begin{array}{r}63.99 \\
.04 \\
19.26 \\
.02 \\
.00 \\
.05 \\
.00 \\
.26 \\
16.06 \\
.00 \\
.00\end{array}$ & $\begin{array}{r}66.15 \\
.00 \\
19.02 \\
.00 \\
.00 \\
.00 \\
.02 \\
.027 \\
16.35 \\
.00 \\
.00\end{array}$ & $\begin{array}{r}64.62 \\
.13 \\
19.27 \\
.00 \\
.00 \\
.00 \\
.02 \\
.35 \\
16.54 \\
.00 \\
.00\end{array}$ & $\begin{array}{r}65.95 \\
.12 \\
19.72 \\
.00 \\
.00 \\
.00 \\
.00 \\
.64 \\
15.05 \\
.00 \\
.00\end{array}$ & $\begin{array}{r}64.57 \\
.00 \\
19.78 \\
.13 \\
.00 \\
.05 \\
.02 \\
1.09 \\
15.33 \\
.00 \\
.00\end{array}$ & $\begin{array}{r}66.00 \\
.03 \\
19.68 \\
.01 \\
.00 \\
.00 \\
.02 \\
1.26 \\
14.00 \\
.00 \\
.00\end{array}$ & $\begin{array}{r}65.43 \\
.00 \\
19.01 \\
.06 \\
.02 \\
.00 \\
.00 \\
1.06 \\
15.32 \\
.00 \\
.00\end{array}$ & $\begin{array}{r}65.43 \\
.00 \\
19.62 \\
.00 \\
.00 \\
.00 \\
.02 \\
1.12 \\
15.30 \\
.00 \\
.00\end{array}$ & $\begin{array}{r}65.64 \\
.03 \\
19.49 \\
.02 \\
.00 \\
.01 \\
.01 \\
1.00 \\
15.25 \\
.00 \\
.00\end{array}$ & $\begin{array}{r}65.30 \\
.00 \\
19.25 \\
.00 \\
.00 \\
.00 \\
.00 \\
1.05 \\
15.76 \\
.00 \\
.00\end{array}$ & $\begin{array}{r}65.37 \\
.07 \\
19.04 \\
.15 \\
.00 \\
.00 \\
.02 \\
.21 \\
16.36 \\
.00 \\
.00\end{array}$ & $\begin{array}{r}65.54 \\
.09 \\
19.07 \\
.07 \\
.02 \\
.03 \\
.00 \\
1.06 \\
15.54 \\
.00 \\
.00\end{array}$ \\
\hline
\end{tabular}

TOTAL $100.49101 .32 \quad 100.78 \quad 99.99 \quad 100.49 \quad 99.50 \quad 98.55 \quad 100.26 \quad 101.80 \quad 101.04 \quad 102.27 \quad 100.98 \quad 100.87 \quad 101.71 \quad 101.56 \quad 101.56 \quad 101.38 \quad 101.21 \quad 101.42$ 
K-FELDSPAR ANALYSES

\begin{tabular}{|c|c|c|c|c|c|c|c|c|c|c|c|c|c|c|c|c|c|c|c|}
\hline tole & 2 & 2 & 2 & 2 & 2 & 2 & 2 & 2 & 2 & 2 & 3 & 3 & 3 & 3 & 3 & 3 & 3 & 3 & 3 \\
\hline Depth & 6.87 & 6.87 & 6.87 & 5.67 & 6.87 & 6.87 & 7.27 & 8.00 & 8.00 & 8,00 & 3.83 & 3.83 & 3.83 & 3.63 & ID.t. & I6.04 & 10.04 & 10.04 & 14.45 \\
\hline $\begin{array}{l}\mathrm{SiO}_{2} \\
\mathrm{~T}_{2} \mathrm{O}_{2} \\
\mathrm{Al}_{2} \mathrm{O}_{3} \\
\mathrm{FeO}^{\circ} \\
\mathrm{MgO} \\
\mathrm{MnO} \\
\mathrm{CaO} \\
\mathrm{Na}_{2} \mathrm{O} \\
\mathrm{M}_{2} \mathrm{O} \\
\mathrm{P}_{2} \mathrm{O}_{5} \\
\mathrm{~F}\end{array}$ & $\begin{array}{r}65.54 \\
.09 \\
19.07 \\
.07 \\
.02 \\
.03 \\
.00 \\
1.06 \\
15.54 \\
.00 \\
.00\end{array}$ & $\begin{array}{r}65.22 \\
18.16 \\
.12 \\
.02 \\
.03 \\
.00 \\
1.01 \\
15.39 \\
.00 \\
.00\end{array}$ & $\begin{array}{r}64.69 \\
19.16 \\
19.09 \\
.02 \\
.03 \\
.02 \\
1.31 \\
14.55 \\
.09 \\
.00\end{array}$ & $\begin{array}{r}63.51 \\
19.29 \\
.11 \\
.00 \\
.00 \\
.09 \\
1.50 \\
14.50 \\
.00 \\
.00\end{array}$ & $\begin{array}{r}64.54 \\
18.07 \\
.07 \\
.01 \\
.01 \\
.00 \\
.70 \\
15.90 \\
.00 \\
.00\end{array}$ & $\begin{array}{r}65.07 \\
19.04 \\
.08 \\
.00 \\
.00 \\
.00 \\
1.06 \\
15.53 \\
.00 \\
.00\end{array}$ & $\begin{array}{r}64.42 \\
.00 \\
18.53 \\
.05 \\
.00 \\
.00 \\
.00 \\
.63 \\
15.98 \\
.00 \\
.00\end{array}$ & $\begin{array}{r}65.11 \\
.00 \\
19.00 \\
.14 \\
.00 \\
.03 \\
.03 \\
1.20 \\
14.95 \\
.00 \\
.00\end{array}$ & $\begin{array}{r}65.03 \\
18.02 \\
.08 \\
.00 \\
.00 \\
.00 \\
1.13 \\
14.03 \\
.00 \\
.00\end{array}$ & $\begin{array}{r}65.72 \\
18.02 \\
.07 \\
.00 \\
.01 \\
.00 \\
.31 \\
15.92 \\
.00 \\
.00\end{array}$ & $\begin{array}{r}63.76 \\
18.00 \\
.00 \\
.02 \\
.00 \\
.00 \\
.18 \\
16.20 \\
.00 \\
.00\end{array}$ & $\begin{array}{r}64.88 \\
19.14 \\
.00 \\
.02 \\
.00 \\
.00 \\
.20 \\
16.36 \\
.00 \\
.00\end{array}$ & $\begin{array}{r}65.03 \\
19.00 \\
.07 \\
.00 \\
.00 \\
.00 \\
.28 \\
16.34 \\
.00 \\
.00\end{array}$ & $\begin{array}{r}62.17 \\
.00 \\
18.70 \\
.07 \\
.00 \\
.00 \\
.00 \\
.11 \\
16.00 \\
.00 \\
.00\end{array}$ & $\begin{array}{r}64.65 \\
.57 \\
19.44 \\
.00 \\
.00 \\
.00 \\
.00 \\
.25 \\
16.25 \\
.00 \\
.00\end{array}$ & $\begin{array}{r}65.92 \\
19.00 \\
.00 \\
.00 \\
.00 \\
.05 \\
.25 \\
16.07 \\
.00 \\
.00\end{array}$ & $\begin{array}{r}64.71 \\
.15 \\
19.38 \\
.00 \\
.00 \\
.00 \\
.00 \\
1.08 \\
14.86 \\
.00 \\
.00\end{array}$ & $\begin{array}{r}64.86 \\
.42 \\
18.98 \\
.00 \\
.00 \\
.00 \\
.00 \\
1.60 \\
14.28 \\
.00 \\
.00\end{array}$ & $\begin{array}{l}.00 \\
.00 \\
.00 \\
.00 \\
.00 \\
.00 \\
.00 \\
.00 \\
.00 \\
.00 \\
.00\end{array}$ \\
\hline
\end{tabular}

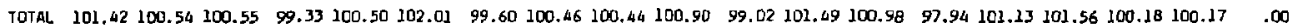

\section{K-FELDSPAR ANALYSES}

Hole 66

oepth 7.757 .75

\begin{tabular}{lrr}
\hline $\mathrm{SIO}_{2}$ & 65.01 & 65.07 \\
$\mathrm{THO}_{2}$ & .00 & .00 \\
$\mathrm{Al}_{2} \mathrm{O}_{3}$ & 19.55 & 19.19 \\
$\mathrm{FeO}^{2}$ & .14 & .00 \\
$\mathrm{MgO}$ & .04 & .04 \\
$\mathrm{MnO}$ & .00 & .00 \\
$\mathrm{CgO}$ & .03 & .02 \\
$\mathrm{Na}_{2} \mathrm{O}$ & .24 & .22 \\
$\mathrm{~K}_{2} \mathrm{O}$ & 16.29 & 16.64 \\
$\mathrm{P}_{2} \mathrm{O}_{5}$ & .00 & .00 \\
$\mathrm{~F}^{2}$ & .00 & .00
\end{tabular}

TOTAL 101.30101 .83 
BIOTITE ANALYSES

\begin{tabular}{|c|c|c|c|c|c|c|c|c|c|c|c|c|c|c|c|c|c|}
\hline Hole & 1 & 1 & 1 & 1 & 1 & 1 & 1 & 1 & 1 & 1 & 1 & 1 & 1 & 2 & 2 & 2 & 2 \\
\hline Depth & 2.17 & 2.45 & 2.45 & 2.45 & 2.78 & 2.78 & 6.40 & 6.40 & 6.75 & 6.75 & $6.7 \overline{5}$ & 16.44 & 16.47 & 7.27 & 7.27 & 8.00 & 8.00 \\
\hline 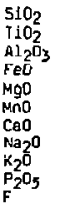 & $\begin{array}{r}35.98 \\
3.19 \\
15.28 \\
18.20 \\
11.37 \\
.59 \\
.02 \\
.03 \\
9.68 \\
.06 \\
.44\end{array}$ & $\begin{array}{r}36.29 \\
2.75 \\
15.28 \\
18.78 \\
11.46 \\
.64 \\
.02 \\
.15 \\
5.23 \\
.04 \\
.92\end{array}$ & $\begin{array}{r}36.91 \\
3.0 \\
14.66 \\
18.79 \\
11.29 \\
.56 \\
.05 \\
.10 \\
9.23 \\
.00 \\
.36\end{array}$ & $\begin{array}{r}34.61 \\
3.43 \\
15.50 \\
18.92 \\
11.48 \\
.55 \\
.07 \\
.09 \\
9.65 \\
.00 \\
.26\end{array}$ & $\begin{array}{r}37.99 \\
.35 \\
15.44 \\
16.49 \\
12.96 \\
.75 \\
.01 \\
.11 \\
10.18 \\
.16 \\
.74\end{array}$ & $\begin{array}{r}37.45 \\
2.06 \\
25.44 \\
16.62 \\
22.61 \\
.80 \\
.12 \\
.10 \\
9.56 \\
.00 \\
.71\end{array}$ & $\begin{array}{r}37.82 \\
3.38 \\
16.16 \\
12.84 \\
25.26 \\
.94 \\
.03 \\
.03 \\
9.81 \\
.05 \\
.68\end{array}$ & $\begin{array}{r}37.59 \\
3.59 \\
15.92 \\
13.21 \\
15.03 \\
.99 \\
.03 \\
.04 \\
9.61 \\
.00 \\
.41\end{array}$ & $\begin{array}{r}37.24 \\
2.72 \\
16.66 \\
18.99 \\
11.55 \\
.60 \\
.02 \\
.07 \\
9.66 \\
.02 \\
.51\end{array}$ & $\begin{array}{r}37.72 \\
2.54 \\
15.58 \\
15.08 \\
12.37 \\
.67 \\
.02 \\
.04 \\
9.91 \\
.00 \\
.50\end{array}$ & $\begin{array}{r}36.47 \\
3.13 \\
15.40 \\
19.38 \\
11.03 \\
.67 \\
.00 \\
.03 \\
9.62 \\
.08 \\
.56\end{array}$ & $\begin{array}{r}36.93 \\
3.47 \\
15.80 \\
17.71 \\
12.16 \\
.62 \\
.02 \\
.10 \\
9.81 \\
.11 \\
.65\end{array}$ & $\begin{array}{r}37.58 \\
3.65 \\
16.15 \\
18.03 \\
12.30 \\
.68 \\
.00 \\
.12 \\
10.00 \\
.11 \\
. .33\end{array}$ & $\begin{array}{r}36.56 \\
2.62 \\
1.5 .32 \\
18.80 \\
12.00 \\
.66 \\
.02 \\
.12 \\
9.66 \\
.00 \\
.40\end{array}$ & $\begin{array}{r}35.89 \\
3.67 \\
15.13 \\
19.51 \\
11.00 \\
.58 \\
.05 \\
.12 \\
9.55 \\
.00 \\
.43\end{array}$ & $\begin{array}{r}36.54 \\
3.50 \\
15.04 \\
18.75 \\
11.28 \\
.58 \\
.02 \\
.08 \\
9.35 \\
.05 \\
.46\end{array}$ & $\begin{array}{r}37.76 \\
3.04 \\
15.32 \\
28.92 \\
11.59 \\
.57 \\
.00 \\
.10 \\
9.49 \\
.00 \\
.62\end{array}$ \\
\hline TOTAL & 94.04 & 95.56 & 95.08 & 94.52 & 95.16 & 95.49 & 97.10 & 96.41 & 98.95 & 98.43 & 96.33 & 97.37 & 90.93 & 96.17 & 95.93 & 95.66 & 97.41 \\
\hline
\end{tabular}




\section{EPIDOTE ANALYSES}

\begin{tabular}{|c|c|c|c|c|c|c|c|c|c|c|c|c|c|c|c|c|c|}
\hline Hole & 1 & 1 & ] & 1 & 1 & 1 & 2 & 2 & 2 & 2 & 2 & 2 & 2 & 3 & 3 & 3 & 3 \\
\hline Depth & 2.17 & 2.17 & 2.17 & 2.78 & 2,78 & 2.78 & 6.87 & 6.87 & 6.87 & 6.67 & 7.27 & 0.00 & 0.00 & 6.90 & 6.90 & 10.04 & 10.04 \\
\hline 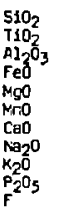 & $\begin{array}{r}35.83 \\
.00 \\
24.34 \\
11.04 \\
.00 \\
.00 \\
23.56 \\
.00 \\
.03 \\
.00 \\
.00\end{array}$ & $\begin{array}{r}37.77 \\
.52 \\
24.92 \\
11.12 \\
.01 \\
.17 \\
23.26 \\
.00 \\
.00 \\
.00 \\
.00\end{array}$ & $\begin{array}{r}37.16 \\
.20 \\
24.09 \\
10.43 \\
.02 \\
.22 \\
23.65 \\
.00 \\
.00 \\
.00 \\
.00\end{array}$ & $\begin{array}{r}38.32 \\
.00 \\
24.00 \\
11.57 \\
.05 \\
.45 \\
23.23 \\
.00 \\
.00 \\
.00 \\
.00\end{array}$ & $\begin{array}{r}38.67 \\
.00 \\
25.64 \\
10.71 \\
.25 \\
.30 \\
23.72 \\
.00 \\
.07 \\
.00 \\
.00\end{array}$ & $\begin{array}{r}38.32 \\
.00 \\
24.74 \\
12.12 \\
.05 \\
.96 \\
22.94 \\
.00 \\
.00 \\
.00 \\
.00\end{array}$ & $\begin{array}{r}38.02 \\
.35 \\
21.90 \\
14.20 \\
.00 \\
.16 \\
22.90 \\
.00 \\
.00 \\
.00 \\
.07\end{array}$ & $\begin{array}{r}37.88 \\
.54 \\
23.02 \\
13.37 \\
.13 \\
.24 \\
22.83 \\
.00 \\
.01 \\
.02 \\
.15\end{array}$ & $\begin{array}{r}37.92 \\
.11 \\
22.38 \\
14.58 \\
.01 \\
.10 \\
22.84 \\
.02 \\
.00 \\
.14 \\
.00\end{array}$ & $\begin{array}{r}38.58 \\
1.52 \\
24.90 \\
9.85 \\
.14 \\
.17 \\
23.39 \\
.00 \\
.00 \\
.00 \\
.13\end{array}$ & $\begin{array}{r}37.58 \\
.19 \\
21.66 \\
14.57 \\
.03 \\
.12 \\
23.21 \\
.00 \\
.00 \\
.00 \\
.06\end{array}$ & $\begin{array}{r}37.64 \\
1.17 \\
21.95 \\
13.64 \\
.04 \\
.22 \\
22.92 \\
.00 \\
.02 \\
.00 \\
.18\end{array}$ & $\begin{array}{r}37.46 \\
.28 \\
22.20 \\
13.64 \\
.00 \\
0.56 \\
21.85 \\
.00 \\
.02 \\
.00 \\
.00\end{array}$ & $\begin{array}{r}37.88 \\
.00 \\
28.09 \\
8.23 \\
.00 \\
.05 \\
22.73 \\
.00 \\
.01 \\
.15 \\
.00\end{array}$ & $\begin{array}{r}39.20 \\
.00 \\
27.89 \\
7.59 \\
.00 \\
.00 \\
23.32 \\
.02 \\
.04 \\
.05 \\
.00\end{array}$ & $\begin{array}{r}38.46 \\
.15 \\
24.23 \\
12.58 \\
.41 \\
.29 \\
23.05 \\
.00 \\
.00 \\
.00 \\
.00\end{array}$ & $\begin{array}{r}37.37 \\
.87 \\
23.03 \\
13.37 \\
.02 \\
.22 \\
22.19 \\
.00 \\
.03 \\
.05 \\
.00\end{array}$ \\
\hline
\end{tabular}

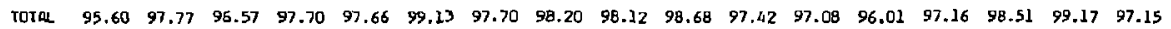

EPIDOTE ANALYSES

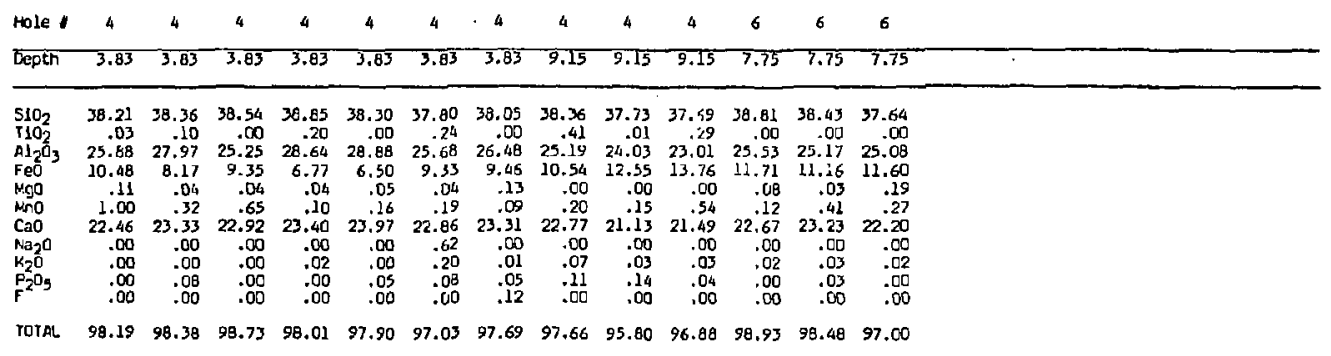


MUSCOVITE ANRLYSES

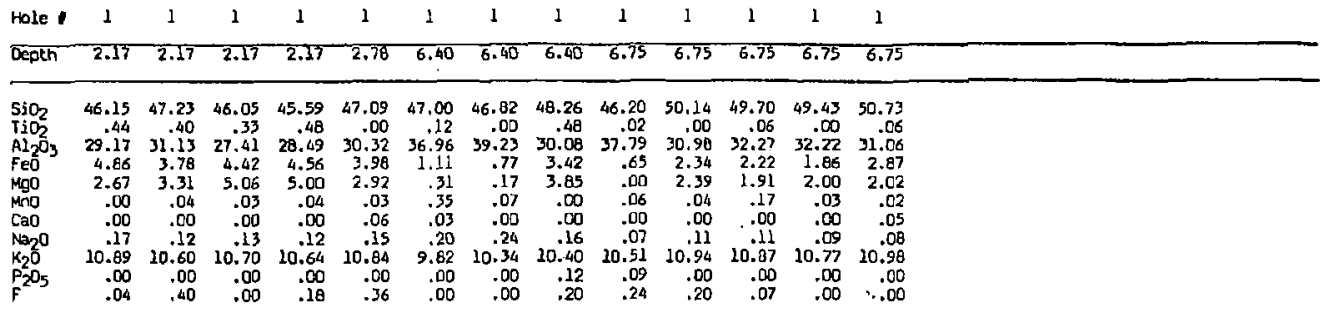

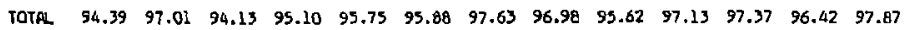

\section{MUSCOVITE ANRLYSES}

\begin{tabular}{|c|c|c|c|c|c|c|c|c|c|c|c|c|c|c|c|c|c|c|c|}
\hline Hole & 1 & 2 & 1 & 1 & 1 & 1 & 1 & 1 & 1 & 1 & 1 & 1 & 1 & 1 & 1 & 1 & 1 & 1 & 1 \\
\hline Depth & 13.80 & 13.80 & 13.90 & 13.80 & 13.80 & 13.80 & 13.80 & 13.80 & $14 . \overline{42}$ & 14,42 & 14.42 & 14,42 & 14.42 & 14.42 & $14 . \overline{42}$ & 14.42 & $1 \longdiv { 4 . 4 2 }$ & 16.47 & 16.47 \\
\hline $\begin{array}{l}\mathrm{SiO}_{2} \\
\mathrm{THO}_{2} \\
\mathrm{Al}_{2} \mathrm{O}_{3} \\
\mathrm{feO} \\
\mathrm{MgO} \\
\mathrm{MnO} \\
\mathrm{CaO} \\
\mathrm{Hea}_{2} \mathrm{O} \\
\mathrm{K}_{2} \mathrm{O}^{\circ} \\
\mathrm{P}_{2} \mathrm{O}_{5} \\
\mathrm{~F}^{2}\end{array}$ & $\begin{array}{r}50.68 \\
.11 \\
29.61 \\
2.98 \\
2.23 \\
.03 \\
.05 \\
.07 \\
10.88 \\
.00 \\
.00\end{array}$ & $\begin{array}{r}50.40 \\
.00 \\
30.79 \\
2.88 \\
2.05 \\
.10 \\
.00 \\
.07 \\
11.19 \\
.06 \\
.12\end{array}$ & $\begin{array}{r}47.08 \\
.87 \\
30.12 \\
2.99 \\
3.05 \\
.02 \\
.03 \\
.18 \\
11.13 \\
.00 \\
.00\end{array}$ & $\begin{array}{r}47.03 \\
.49 \\
28.40 \\
3.34 \\
3.80 \\
.07 \\
.20 \\
.20 \\
10.83 \\
.02 \\
.12\end{array}$ & $\begin{array}{r}47.83 \\
.03 \\
30.09 \\
2.04 \\
2.52 \\
.09 \\
.05 \\
.11 \\
10.74 \\
.02 \\
.10\end{array}$ & $\begin{array}{r}48.13 \\
.09 \\
29.96 \\
3.22 \\
3.23 \\
.04 \\
.02 \\
.21 \\
10.95 \\
.08 \\
.12\end{array}$ & $\begin{array}{r}47.94 \\
.41 \\
30.59 \\
3.38 \\
3.78 \\
.08 \\
.02 \\
.22 \\
11.33 \\
.00 \\
.15\end{array}$ & $\begin{array}{r}46.33 \\
.49 \\
27.92 \\
4.02 \\
4.99 \\
.06 \\
.00 \\
.16 \\
10.97 \\
.02 \\
.17\end{array}$ & $\begin{array}{r}40.45 \\
.00 \\
30.36 \\
1.40 \\
2.28 \\
.00 \\
.05 \\
.06 \\
10.88 \\
.05 \\
.14\end{array}$ & $\begin{array}{r}50.03 \\
.06 \\
32.71 \\
.85 \\
2.23 \\
.00 \\
.00 \\
.10 \\
10.07 \\
.00 \\
.00\end{array}$ & $\begin{array}{r}48.92 \\
.53 \\
33.47 \\
.00 \\
1.87 \\
.00 \\
.04 \\
.10 \\
10.66 \\
.00 \\
.00\end{array}$ & $\begin{array}{r}47.11 \\
.70 \\
30.00 \\
2.94 \\
3.23 \\
.00 \\
.07 \\
.13 \\
10.69 \\
.00 \\
.16\end{array}$ & $\begin{array}{r}46.24 \\
.95 \\
29.75 \\
3.11 \\
3.31 \\
.06 \\
.02 \\
.15 \\
10.94 \\
.00 \\
.05\end{array}$ & $\begin{array}{r}49.03 \\
.03 \\
31.86 \\
2.48 \\
2.32 \\
+00 \\
.04 \\
.18 \\
10.75 \\
.00 \\
.12\end{array}$ & $\begin{array}{r}48.24 \\
.63 \\
31.08 \\
2.78 \\
3.74 \\
.04 \\
.01 \\
.025 \\
11.12 \\
.07 \\
.43\end{array}$ & $\begin{array}{r}47.09 \\
.14 \\
27.23 \\
4.24 \\
5.74 \\
.00 \\
.00 \\
.15 \\
11.03 \\
.00 \\
.23\end{array}$ & $\begin{array}{r}49.75 \\
.07 \\
32.31 \\
1.47 \\
2.18 \\
.00 \\
.03 \\
.16 \\
10.60 \\
.00 \\
.14\end{array}$ & $\begin{array}{r}47.58 \\
.71 \\
30.41 \\
3.64 \\
2.86 \\
.01 \\
.00 \\
.14 \\
11.07 \\
.00 \\
.07\end{array}$ & $\begin{array}{r}46.47 \\
.35 \\
29.19 \\
4.60 \\
4.78 \\
.06 \\
.00 \\
.14 \\
10.91 \\
.05 \\
.11\end{array}$ \\
\hline TOTAL & 96.64 & 97,66 & 95,47 & 94.32 & 93.60 & 96.02 & 97.91 & 95.13 & 93.72 & 97.14 & 95.59 & 95.07 & 96.58 & 96.82 & 98.38 & 96.21 & 96.71 & 96.70 & 96.67 \\
\hline
\end{tabular}


MUSCOVITE ANAL YSES

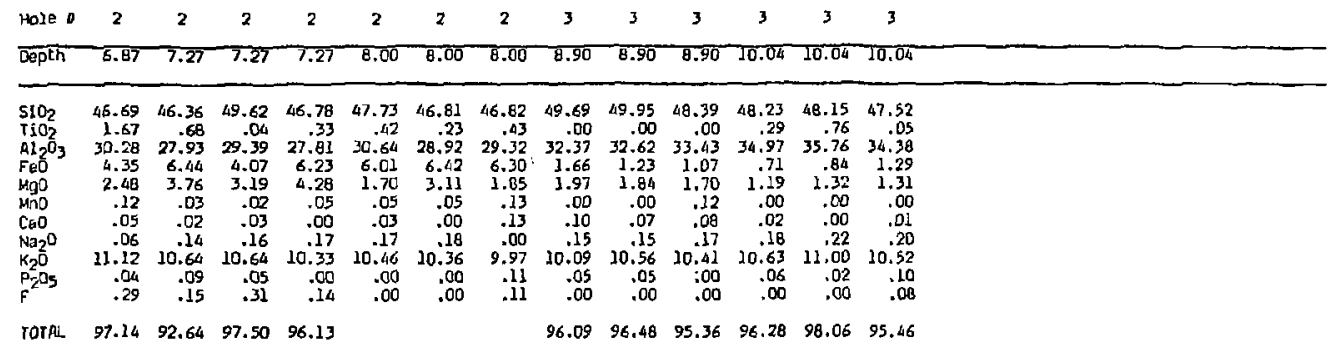

MUSCOVIIE ANRLYSES

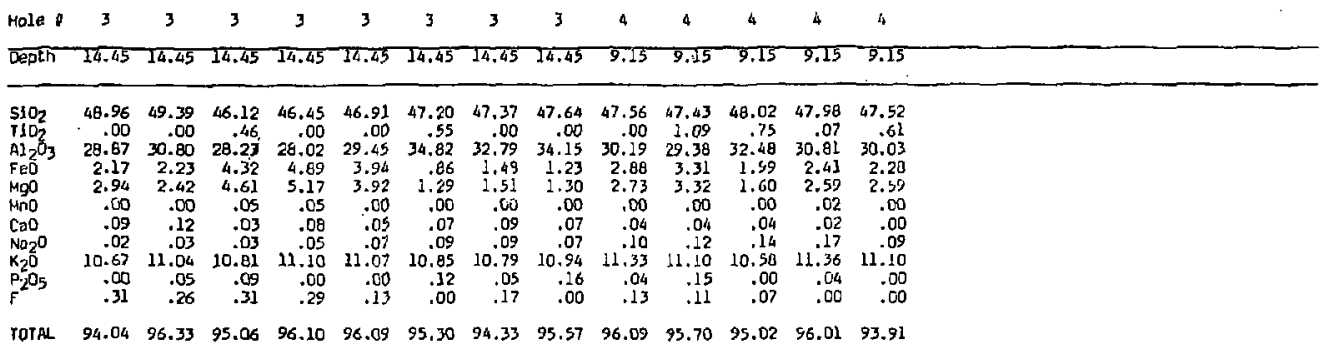


MUSCOVITE ANALYSES

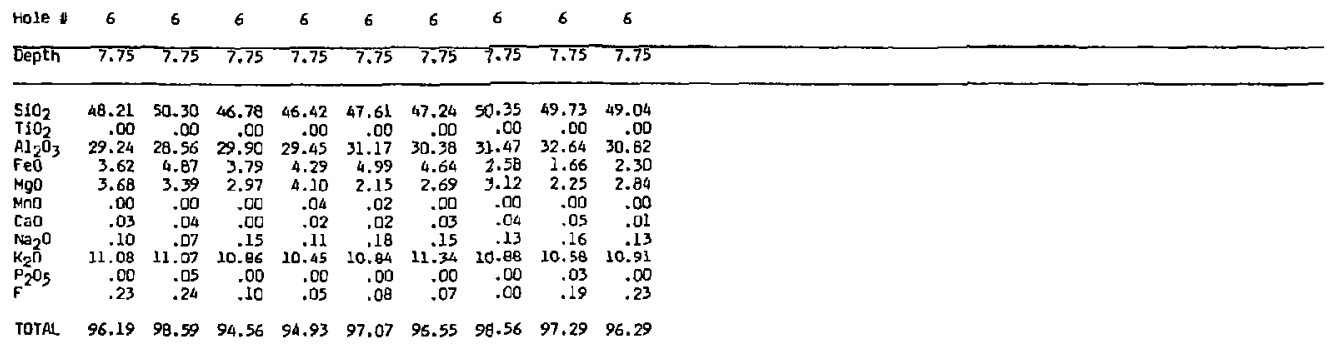




\section{CLIMOZOISITE ANALYSES}

\begin{tabular}{|c|c|c|c|c|c|c|c|c|c|c|c|c|c|c|c|c|c|}
\hline Hole & 1 & 2 & 2 & 2 & 2 & 2 & 3 & 3 & 3 & 3 & 3 & 3 & 3 & 3 & 3 & 3 & 3 \\
\hline Depth & 2.17 & 3.83 & 3.83 & 3.83 & 7.27 & 7.27 & B.90 & 8.90 & 8.90 & 8.90 & 8.90 & 10.04 & 10.04 & 10.04 & 10.04 & 10.04 & $\widehat{10.04}$ \\
\hline $\begin{array}{l}\mathrm{S}_{2} \mathrm{O}_{2} \\
\mathrm{TiO}_{2} \\
\mathrm{Al}_{2} \mathrm{O}_{3} \\
\mathrm{FeO} \\
\mathrm{MgO} \\
\mathrm{MnO} \\
\mathrm{CaO} \\
\mathrm{Na}_{2} \mathrm{O} \\
\mathrm{K}_{2} \mathrm{O} \\
\mathrm{P}_{2} \mathrm{O}_{5} \\
\mathrm{~F}\end{array}$ & $\begin{array}{r}38.60 \\
.00 \\
34.31 \\
.65 \\
.06 \\
.12 \\
25.17 \\
.00 \\
.01 \\
.02 \\
.00\end{array}$ & $\begin{array}{r}39.41 \\
.19 \\
34.02 \\
.09 \\
.00 \\
.00 \\
24.60 \\
.02 \\
.00 \\
.00 \\
.00\end{array}$ & $\begin{array}{r}39.62 \\
.00 \\
33.69 \\
1.02 \\
.01 \\
.00 \\
24.76 \\
.00 \\
.02 \\
.00 \\
.00\end{array}$ & $\begin{array}{r}39.20 \\
.00 \\
31.34 \\
3.90 \\
.08 \\
.99 \\
27.95 \\
.00 \\
.01 \\
.23 \\
.00\end{array}$ & $\begin{array}{r}30.99 \\
.07 \\
30.79 \\
4.04 \\
.04 \\
.53 \\
23.58 \\
.00 \\
.00 \\
.10 \\
.00\end{array}$ & $\begin{array}{r}38.56 \\
.00 \\
31.41 \\
3.55 \\
.09 \\
.80 \\
24.03 \\
.00 \\
.00 \\
.06 \\
.00\end{array}$ & $\begin{array}{r}39.69 \\
.00 \\
33.11 \\
2.02 \\
.00 \\
.70 \\
23.10 \\
.02 \\
.01 \\
.12 \\
.00\end{array}$ & $\begin{array}{r}39.70 \\
.00 \\
32.55 \\
1.59 \\
.00 \\
.43 \\
23.36 \\
.09 \\
.00 \\
.00 \\
.00\end{array}$ & $\begin{array}{r}39.43 \\
.00 \\
31.32 \\
4.00 \\
.02 \\
.00 \\
23.33 \\
.00 \\
.02 \\
.08 \\
.00\end{array}$ & $\begin{array}{r}39.73 \\
.00 \\
33.72 \\
1.29 \\
.12 \\
.00 \\
24.01 \\
.04 \\
.03 \\
.00 \\
.00\end{array}$ & $\begin{array}{r}39.87 \\
.00 \\
34.39 \\
.30 \\
.00 \\
.00 \\
24.08 \\
.00 \\
.00 \\
.00 \\
.00\end{array}$ & $\begin{array}{r}38.52 \\
.20 \\
29.24 \\
6.23 \\
.03 \\
.55 \\
23.03 \\
.00 \\
.00 \\
.02 \\
.00\end{array}$ & $\begin{array}{r}39.08 \\
.04 \\
29.57 \\
6.31 \\
.03 \\
.44 \\
23.14 \\
.00 \\
.00 \\
.24 \\
.00\end{array}$ & $\begin{array}{r}38.81 \\
.05 \\
28.86 \\
6.75 \\
.04 \\
.39 \\
23.60 \\
.00 \\
.00 \\
.02 \\
.00\end{array}$ & $\begin{array}{r}38.52 \\
.47 \\
28.90 \\
7.45 \\
.03 \\
.59 \\
23.08 \\
.00 \\
.00 \\
.13 \\
.00\end{array}$ & $\begin{array}{r}38.70 \\
.22 \\
26.34 \\
9.79 \\
.03 \\
.10 \\
23.37 \\
.00 \\
.00 \\
.00 \\
.00\end{array}$ & $\begin{array}{r}38.70 \\
.59 \\
28.10 \\
8.08 \\
.08 \\
1.51 \\
21.74 \\
.00 \\
.00 \\
.31 \\
.00\end{array}$ \\
\hline TOTA & 98.96 & 99.16 & 99.12 & 98.79 & 98.65 & 98.68 & 98.77 & 97.68 & 98.20 & 98.93 & 98.80 & 97.82 & 59.44 & 98.52 & 99.15 & 98.76 & 98.90 \\
\hline
\end{tabular}


CHLCRIIE ANAL YSES

\begin{tabular}{|c|c|c|c|c|c|c|c|c|c|c|c|c|c|c|c|c|c|c|c|}
\hline Hole & 1 & 1 & 1 & 1 & 1 & 1 & 1 & 1 & 1 & 1 & 1 & 1 & 1 & 1 & 1 & 1 & 2 & 2 & 2 \\
\hline$\overline{\text { Depth }}$ & 2,45 & 2.45 & 2.78 & 2.78 & 2.78 & 2.78 & 2.80 & 6.40 & 6.75 & 6.75 & 6.75 & 6.75 & $14 . \overline{42}$ & 16.47 & 16.47 & 16.47 & 6.87 & 6.87 & 6.87 \\
\hline $\begin{array}{l}\mathrm{SHO}_{2} \\
\mathrm{THO}_{2} \\
\mathrm{Al}_{2} \mathrm{O}_{3} \\
\mathrm{FeO} \\
\mathrm{MgO} \\
\mathrm{MnO} \\
\mathrm{CaO} \\
\mathrm{Na}_{2} \mathrm{O} \\
\mathrm{K}_{2} \mathrm{O} \\
\mathrm{P}_{20} \mathrm{O}_{5} \\
\mathrm{~F}^{\circ}\end{array}$ & $\begin{array}{r}27.20 \\
.44 \\
19.54 \\
24.57 \\
15.72 \\
.93 \\
.33 \\
.00 \\
.03 \\
.04 \\
.21\end{array}$ & $\begin{array}{r}25.65 \\
.00 \\
20.45 \\
24.08 \\
15.40 \\
.95 \\
.06 \\
.00 \\
.02 \\
.04 \\
.00\end{array}$ & $\begin{array}{r}27.40 \\
.00 \\
20.10 \\
18.69 \\
19.95 \\
.83 \\
.02 \\
.00 \\
.00 \\
.12 \\
.15\end{array}$ & $\begin{array}{r}28.17 \\
.00 \\
19.60 \\
19.24 \\
20.85 \\
.79 \\
.03 \\
.80 \\
.12 \\
.05 \\
.17\end{array}$ & $\begin{array}{r}28.28 \\
.00 \\
21.15 \\
17.48 \\
20.40 \\
.87 \\
.03 \\
.00 \\
.17 \\
.00 \\
.14\end{array}$ & $\begin{array}{r}29.03 \\
.00 \\
19.09 \\
16.35 \\
22.32 \\
1.02 \\
.03 \\
.00 \\
.00 \\
.09 \\
.00\end{array}$ & $\begin{array}{r}28.96 \\
.00 \\
17.83 \\
17.37 \\
22.10 \\
.80 \\
.03 \\
.00 \\
.00 \\
.16 \\
.00\end{array}$ & $\begin{array}{r}28.56 \\
.00 \\
19.37 \\
14.25 \\
22.50 \\
.87 \\
.01 \\
.00 \\
.07 \\
.00 \\
.00\end{array}$ & $\begin{array}{r}26.55 \\
.00 \\
19.87 \\
26.19 \\
14.76 \\
.97 \\
.00 \\
.00 \\
.00 \\
.00 \\
.00\end{array}$ & $\begin{array}{r}25.78 \\
.00 \\
20.95 \\
24.35 \\
14.83 \\
1.14 \\
.01 \\
.00 \\
.00 \\
.00 \\
.00\end{array}$ & $\begin{array}{r}26.50 \\
.20 \\
20.51 \\
25.61 \\
14.54 \\
.61 \\
.05 \\
.02 \\
.00 \\
.00 \\
.00\end{array}$ & $\begin{array}{r}25.86 \\
.09 \\
19.57 \\
24.80 \\
15.15 \\
1.44 \\
.02 \\
.00 \\
.04 \\
.00 \\
.00\end{array}$ & $\begin{array}{r}29.40 \\
1.35 \\
20.27 \\
15.43 \\
22.70 \\
.20 \\
.07 \\
.00 \\
.01 \\
.00 \\
.39\end{array}$ & $\begin{array}{r}28.36 \\
.22 \\
19.26 \\
21.82 \\
16.53 \\
.66 \\
.06 \\
.00 \\
.94 \\
.00 \\
.00\end{array}$ & $\begin{array}{r}26.81 \\
.08 \\
22.15 \\
18.47 \\
19.59 \\
.48 \\
.02 \\
.00 \\
.00 \\
.00 \\
.00\end{array}$ & $\begin{array}{r}26.99 \\
.18 \\
20.72 \\
18.42 \\
19.57 \\
.44 \\
.00 \\
.00 \\
.00 \\
.00 \\
.00\end{array}$ & $\begin{array}{r}26.61 \\
.13 \\
19.24 \\
24.65 \\
15.57 \\
.87 \\
.03 \\
.00 \\
.03 \\
.04 \\
.12\end{array}$ & $\begin{array}{r}28.43 \\
3.32 \\
17.84 \\
22.26 \\
13.74 \\
.72 \\
2.76 \\
.00 \\
.61 \\
.04 \\
.12\end{array}$ & $\begin{array}{r}27.10 \\
.00 \\
19.07 \\
28.95 \\
12.03 \\
.50 \\
.05 \\
.00 \\
.00 \\
.02 \\
.00\end{array}$ \\
\hline TOTAL & 89.01 & 86.65 & 87.27 & 89.82 & 88.50 & 87.93 & 87.34 & 85.63 & 80.33 & 07,06 & 80.23 & 86.97 & 89,89 & 87.85 & 87.65 & 86.37 & 07.28 & 65.85 & 87.60 \\
\hline
\end{tabular}

CHLCRITE ANRLYSES

\begin{tabular}{|c|c|c|c|c|c|c|c|c|c|c|c|c|c|c|c|c|c|}
\hline Hole & 2 & 2 & 2 & 2 & 2 & 2 & 2 & 2 & 3 & 3 & 4 & 4 & 6 & 6 & 6 & 6 & 6 \\
\hline Depth & 6.87 & 6.87 & 7.27 & 7.27 & 8.00 & 8.00 & $6 . \overline{00}$ & 8.00 & 10.04 & 10.04 & 3.83 & 3.83 & 7.75 & 7.75 & 7.75 & 7.75 & 7.75 \\
\hline $\begin{array}{l}\mathrm{SHO}_{2} \\
\mathrm{IJO}_{2} \\
\mathrm{Al}_{2} \mathrm{O}_{3} \\
\mathrm{FeO} \\
\mathrm{MgO} \\
\mathrm{MnO} \\
\mathrm{CaO} \\
\mathrm{Na}_{2} \mathrm{O} \\
\mathrm{K}_{2} \mathrm{O} \\
\mathrm{P}_{2} \mathrm{O}_{5} \\
\mathrm{~F}^{2}\end{array}$ & $\begin{array}{r}25.55 \\
.02 \\
29.59 \\
24.35 \\
14.63 \\
.50 \\
.02 \\
.00 \\
.00 \\
.00 \\
.00\end{array}$ & $\begin{array}{r}25.79 \\
.05 \\
21.01 \\
23.71 \\
15.89 \\
.85 \\
.05 \\
.00 \\
.01 \\
.02 \\
.00\end{array}$ & $\begin{array}{r}25.31 \\
.08 \\
21.00 \\
21.33 \\
26.24 \\
.57 \\
.00 \\
.00 \\
.04 \\
.00 \\
.00\end{array}$ & $\begin{array}{r}26.61 \\
.01 \\
20.53 \\
23.66 \\
16.16 \\
.61 \\
.06 \\
.00 \\
.00 \\
.00 \\
.21\end{array}$ & $\begin{array}{r}25.99 \\
.04 \\
20.50 \\
24.38 \\
15.08 \\
.55 \\
.03 \\
.03 \\
.02 \\
.00 \\
.00\end{array}$ & $\begin{array}{r}26.91 \\
.12 \\
20.65 \\
25.06 \\
15.76 \\
.48 \\
.04 \\
.00 \\
.00 \\
.00 \\
.00\end{array}$ & $\begin{array}{r}27.87 \\
.00 \\
20.27 \\
24.41 \\
15.31 \\
.48 \\
.05 \\
.00 \\
.02 \\
.00 \\
.00\end{array}$ & $\begin{array}{r}25.74 \\
.08 \\
20.10 \\
25.33 \\
14.77 \\
.55 \\
.00 \\
.00 \\
.01 \\
.00 \\
.00\end{array}$ & $\begin{array}{r}26.75 \\
1.63 \\
20.69 \\
22.00 \\
16.80 \\
.79 \\
.04 \\
.12 \\
.19 \\
.00 \\
.00\end{array}$ & $\begin{array}{r}27.46 \\
.02 \\
20.43 \\
22.09 \\
16.25 \\
.70 \\
.02 \\
.00 \\
.05 \\
.00 \\
.10\end{array}$ & $\begin{array}{r}27.06 \\
1.54 \\
21.52 \\
18.68 \\
19.01 \\
.72 \\
.02 \\
.08 \\
.05 \\
.09 \\
.04\end{array}$ & $\begin{array}{r}27.15 \\
.03 \\
21.39 \\
20.34 \\
18.77 \\
.84 \\
.00 \\
.00 \\
.04 \\
.20 \\
.13\end{array}$ & $\begin{array}{r}27.53 \\
.00 \\
20.00 \\
21.13 \\
18.72 \\
.17 \\
.03 \\
.00 \\
.03 \\
.00 \\
.00\end{array}$ & $\begin{array}{r}26.88 \\
.00 \\
21.14 \\
21.99 \\
17.83 \\
.15 \\
.05 \\
.05 \\
.02 \\
.00 \\
.00\end{array}$ & $\begin{array}{r}27.22 \\
.00 \\
19.90 \\
25.39 \\
15.46 \\
.80 \\
.04 \\
.00 \\
.00 \\
.06 \\
.00\end{array}$ & $\begin{array}{r}27.20 \\
.00 \\
20.38 \\
25.60 \\
15.36 \\
.79 \\
.04 \\
.00 \\
.00 \\
.00 \\
.00\end{array}$ & $\begin{array}{r}27.45 \\
.00 \\
20.08 \\
25.18 \\
15.23 \\
.80 \\
.04 \\
.00 \\
.00 \\
.00 \\
.00\end{array}$ \\
\hline TOTAL & 85.65 & 87.38 & 84.57 & 87.85 & 86.62 & 89.02 & 88.49 & 86.58 & 89.02 & 87.52 & 88.78 & 88.86 & e7. 50 & 88.13 & 88.97 & 89.37 & 88.78 \\
\hline
\end{tabular}

